経営史学

井数つの 分 ぞ

銀説財た主析れ本

行、 閥本要し、東稿

のがと東な、電の

東存電 電 刘 そ⿱亠乂 課

電在力: 象の東題

介守資東古中邦は

大る。本 邦東で $\sum_{0}$

$つ$ 両 の 社

課

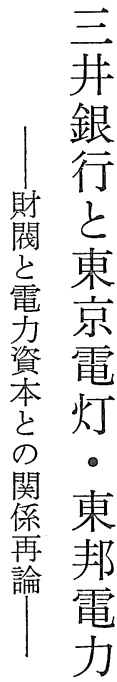

て説関 の 東并経邦銀両電

の分に営の行社力

評加つに両吕と資題

価つい対社他の本

の最てしでの関と

相大はてあ財係の

違の、三つ閥を関

でポ前井た系比係

あイ者銀こ錇較を

る。に

こ と る

介つ者よら隔こ作

入ての ら加絶と業

をい支ににしにの

多の配関したた規る 環

多の娄与た規る。環

数は、強した本箈し

の一守か 稿電者て

よる、无力は

に云多と数々 は金 以曧

財年説うそをに銀

閥 代と論の展財行

に未、点際開閥と

よ加電学十七采東

る $力$ 中分た 金京

支覚心的立と融電

配 $\bigcirc$ 本 的立

橘

の代自取 入三の東

外初立りる开電邦

延 頭性上こ銀力電

的に孝げと行金力

搪か強たがの融

大け調いで電の融

とて方。き力寒下

自のるな金態々

な三少加融を机

郎 
第17巻 第 2 号

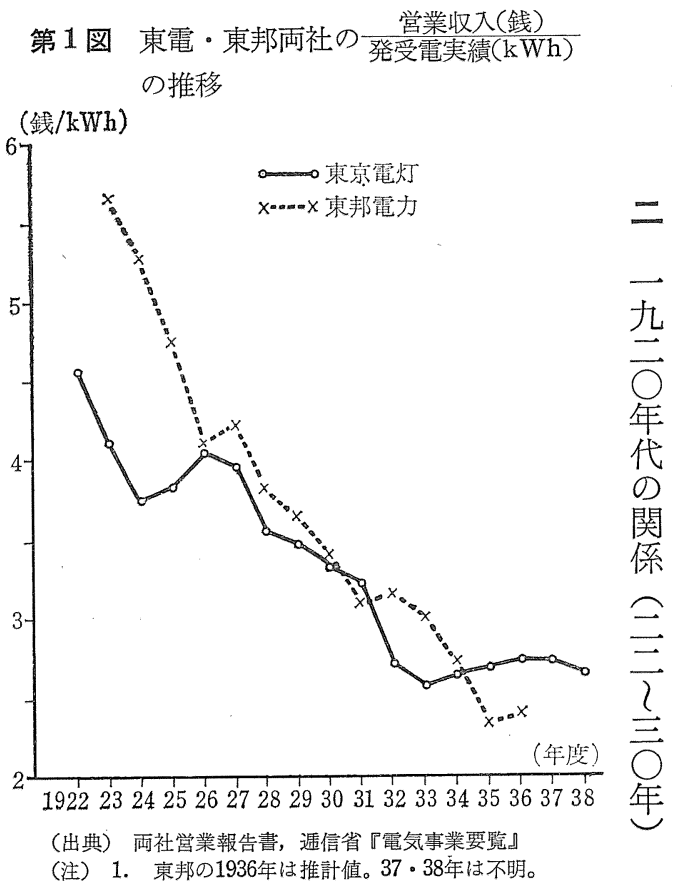

係㤎そてす 発登考把加 比足元前握 較しら後さ少 検たれの机数 討一る時る説 二小九期この 一理三銀東は方 九 由 年行電言に 三丨゙六京経ま権 るか邦嫦で保 代電の简な全 の力関がいた 関管係検。め 係理 分色討三の 法、さ井一 分比机銀 時 成較补行的 立対ばの措 し照な東置 たのら電と 三素な介見 分材い入な 年と。にす ましさつ加 でてらいに の取にてよ 期 y 正 D 間上確て にげ开な つ 5 銀評 財 、水行価閥 て水とをと 、泟東電 三な電す力 开らとた資 銀なのめ本 行 東こ係は関 電就只係 ・がむ入の 東、帮瓷全 声稿緊た像 社で密け㤎 と、だで異 の東っなな 関邦たくっ 
経営史 学

第 2 図 東電・東邦両社の発電力利用率の推移导横 等 技 以

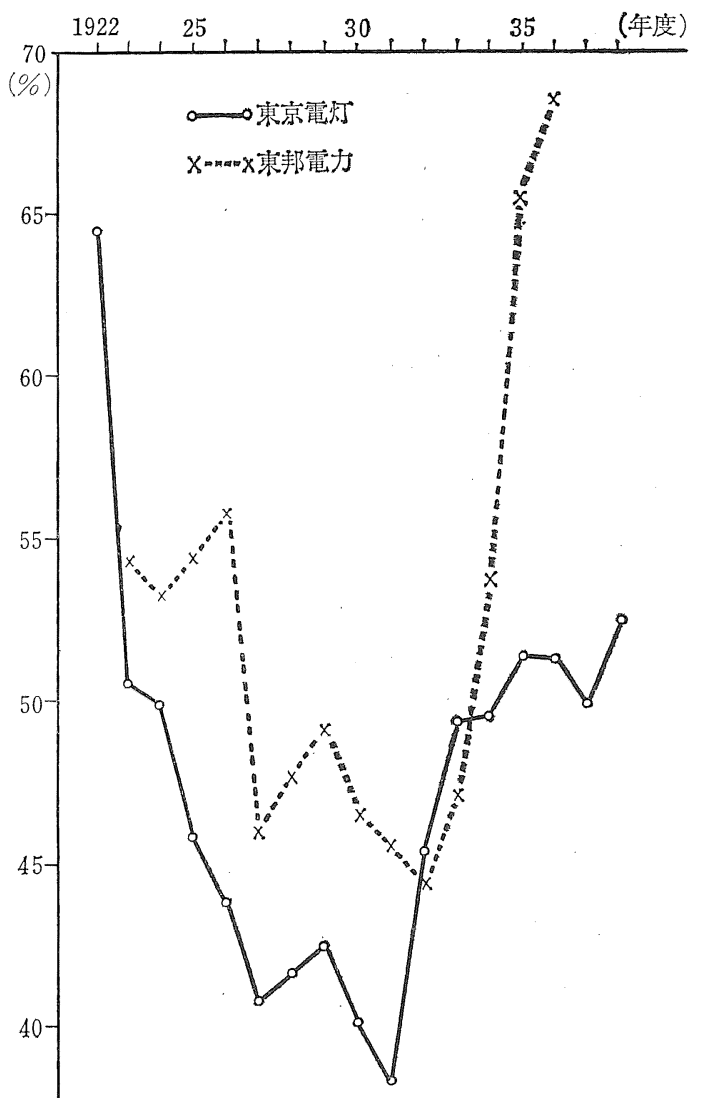

げ浜よ

(1) 東 穴 立 諸 総

や邦電 卸 点資

兄名戦壳う回

電 古上電 ち 転

力屋々力 (1) 率

会・呼会 (2) の

社福ば社4(4) 低

加岡れのは落

ら朝、は

のの 大 興 電 (1)

不 両 都 聥 戦 (5)

な信戦に

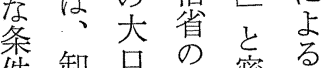

件卸口の密る

で売電大接 す

の電需電に成

電会要家連篝

大の攻争いてた。

(2) 勢 隽て

学戦のた

余爱旎複一

義て開供九

な、さ給 三

さ供れ許 年

狆独。全代

た占大電 の

購 維 市都。

入持に小業

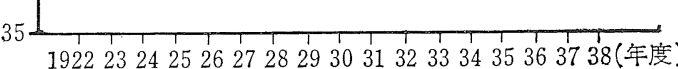

(出典)『東京電灯株式会社史』、東邦電力技術史』，遁信省『電気事業 要臨』

(注) $1 . \frac{\text { 年間発受電実績 }(\mathrm{kWh}) \div \text { 年閏時間数 }(\mathrm{h})}{\text { (前年度末発電力 }} \times 100$ で算出。

2. 購入電力分を含む。
3. 東邦の 1936 年は関西地域 (名古屋周辺) のみ。 $37 ・ 38$ 年は不明。

力方 給 電 江

のた給㫣お

増め域にい

标学ついて

一電つて

九力東 彭

二 料 電 不 距

年金 東許離

年引查可送 
第17巻 第 2 号

の 業 績 の 推 移

(単位：年率\%)

\begin{tabular}{|c|c|c|c|c|c|c|c|c|c|c|}
\hline \multirow{2}{*}{$\begin{array}{l}\text { 回 転 率 } \\
\text { (回) } \\
\text { 東 邦 }\end{array}$} & \multicolumn{2}{|c|}{$\begin{aligned} & (\mathrm{C}=(\mathrm{A}) \times(\mathrm{B}) \\
& \text { 総資本利益率 }\end{aligned}$} & \multicolumn{2}{|c|}{ 払込資本金比率 } & \multicolumn{2}{|c|}{$\begin{array}{l}(\mathrm{B}=\mathrm{C}) \div(\mathrm{D}) \times 100 \\
\text { 払込資本利益率 }\end{array}$} & \multicolumn{4}{|l|}{ 配 } \\
\hline & 東 電 & 東 邦 & 東 電 & 東 邦 & 東 電 & 東 邦 & 東 & & 東 & 邦 \\
\hline 0.21 & 15.4 & 10.7 & 84 & 70 & 18.2 & 15.2 & 1 & & 1 & 3 \\
\hline 0.23 & 13.6 & 9.8 & 76 & 70 & 17.8 & 14.0 & 1 & & 1 & 2 \\
\hline 0.23 & 6.9 & 9.2 & 71 & 66 & 9.7 & 13.9 & $\varepsilon$ & 8 & 1 & 2 \\
\hline 0.22 & 8.0 & 8.3 & 66 & 59 & 12.2 & 14.1 & 10 & 10 & $12 \vdots$ & 12 \\
\hline 0.20 & 7.9 & 7.2 & 59 & 52 & 13.4 & 13.9 & 11 & 11 & 12 & 12 \\
\hline 0.20 & 6.6 & 7.0 & 54 & 49 & 12.1 & 14.2 & 11 & 9 & 12 & 12 \\
\hline 0.20 & 6.0 & 7.0 & 53 & 52 & 11.2 & 13.5 & 9 & 8 & 12 & 10 \\
\hline 0.20 & 5.4 & 6.2 & 50 & 51 & 10.9 & 12.2 & 8 & 8 & 10 & 10 \\
\hline 0.20 & 5.0 & 5.7 & 48 & 47 & 10.4 & 12.3 & 8 & 8 & 10 & 10 \\
\hline 0.17 & 3.3 & 5.2 & 47 & 44 & 7.0 & 11.8 & 5 & 4 & 10 & 8 \\
\hline 0.16 & 2.9 & 5.1 & 46 & 45 & 6.4 & 11.3 & 4 & 3 & 8 & 7 \\
\hline 0.16 & 2.6 & 4.2 & 46 & 44 & 5.7 & 9.6 & 3 & 2 & 7 & 5 \\
\hline 0.17 & 2.5 & 4.0 & 47 & 45 & 5.4 & 8.9 & 0 & 0 & 5 & 5 \\
\hline 0.18 & 3.6 & 6.4 & 47 & 46 & 7.6 & 13.8 & 0 & 4 & 6 & 7 \\
\hline 0.20 & 4.9 & 7.9 & 47 & 52 & 10.5 & 15.2 & 6 & 7 & 7 & 8 \\
\hline 0.21 & 6.0 & 8.4 & 47 & 59 & 12.8 & 14.2 & 8 & 8 & 8 & 8 \\
\hline 0.21 & 5.7 & 8.1 & 46 & 58 & 12.5 & 13.9 & 8 & 8 & 8 & 8 \\
\hline 0.22 & 6.6 & 8.5 & 45 & 61 & 14.8 & 13.9 & 8 & 8 & 8 & 8 \\
\hline
\end{tabular}

2 で算出。なお，各期の平均資本金は（当期末資本金十前期末資本金）－2で算出。

月, 東邦 5 月 10月)。

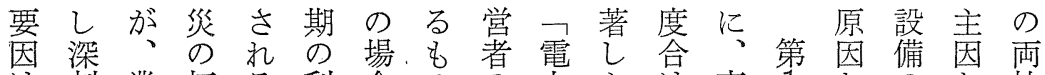
は刻業打る利合のの力的東 1 とのと社 化績撃よ益にで拙戦っ東電表も遊なの 若し不もう率はあ劣した邦のにな休り発 尾た振大にの、っなにがの業あっ化等電 璋基吕き関急三た。文対々そ績るた。年第力

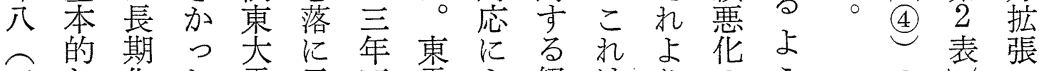

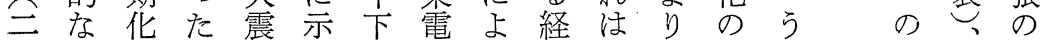


経棠史学

第 1 表 東 電・東 邦 両 社

\begin{tabular}{|c|c|c|c|c|c|c|c|}
\hline \multirow{4}{*}{ 年 } & \multicolumn{6}{|c|}{ (A) } & \multirow{3}{*}{ (B) } \\
\hline & \multirow{2}{*}{\multicolumn{2}{|c|}{$\begin{array}{l}\text { 営業収 入 } \\
\text { 利 益 率 }\end{array}$}} & \multirow{2}{*}{\multicolumn{2}{|c|}{$\begin{array}{ll}\text { 発 受 } & \text { 電 } \\
\text { 費 } \\
\text { 営 } & \text { 收 }\end{array}$}} & \multirow{2}{*}{\multicolumn{2}{|c|}{ 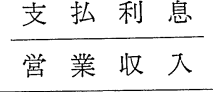 }} & \\
\hline & & & & & & & \\
\hline & 東 電 & 東 邦 & 東＼cjkstart電 & 東 邦 & 東＼cjkstart電 & 東 邦 & 東 電 \\
\hline 1922下 & 59 & 51 & 10 & 25 & 2 & 7 & 0.26 \\
\hline 23上 & 59 & 42 & 15 & 26 & 4 & 9 & 0.23 \\
\hline 下 & 46 & 40 & 9 & 23 & 8 & 11 & 0.15 \\
\hline 24 & 51 & 38 & 15 & 28 & 11 & 14 & 0.16 \\
\hline 25 & 52 & 35 & 21 & 31 & 14 & 15 & 0.15 \\
\hline 26 & 49 & 34 & 20 & 30 & 16 & 15 & 0.14 \\
\hline 27 & 45 & 36 & 23 & 30 & 16 & 14 & 0.13 \\
\hline 28 & 42 & 30 & 24 & 33 & 11 & 13 & 0.13 \\
\hline 29 & 38 & 29 & 28 & 34 & 17 & 15 & 0.13 \\
\hline 30 & 26 & 30 & 31 & 35 & 16 & 18 & 0.13 \\
\hline 31 & 25 & 32 & 29 & 37 & 25 & 20 & 0.12 \\
\hline 32 & 23 & 26 & 28 & 37 & 33 & 23 & 0.12 \\
\hline 33 & 21 & 24 & 27 & 34 & 24 & 24 & 0.12 \\
\hline 34 & 27 & 35 & 29 & 37 & 23 & 15 & 0.13 \\
\hline 35 & 34 & 40 & 25 & 37 & 21 & 11 & 0.15 \\
\hline 36 & 38 & 40 & 24 & 37 & 17 & 7 & 0.16 \\
\hline 37 & 34 & 39 & 25 & 31 & 16 & 6 & 0.17 \\
\hline 38 & 38 & 39 & 25 & 30 & 15 & 5 & 0.17 \\
\hline
\end{tabular}

(出典) 両社営業報告書

（注１１．利益金には償却金，退職給与金引当金を含む。資本金は（上期平均資本金十下期平均資本金）－

2. 配当率の左欄は上期（東電前年 12 月 5 月，東邦前年 11 月 4月），右欗は下期（東電 6 月 11

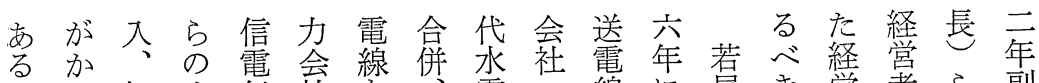

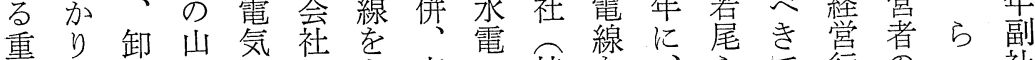

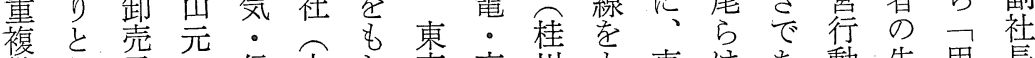
供な電で信天た京京川查沙動先甲長

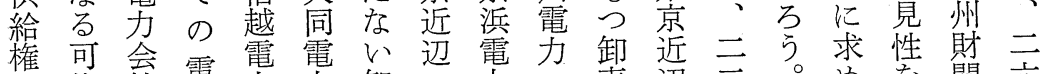

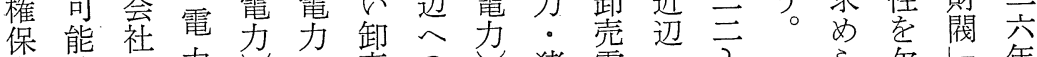

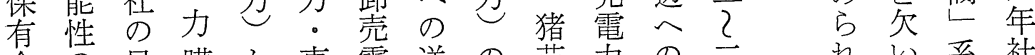
会の足購か東電送の苗力の二机い系社 
第 2 表 東電・東邦両社の発電力拡張過程

(単位: $\mathrm{kW}$ )

\begin{tabular}{|c|c|c|c|c|c|c|c|c|c|c|}
\hline 社 & $\begin{array}{l}\text { 期 間 } \\
\text { (年度) }\end{array}$ & $\frac{\text { 水 }}{\text { (A) }}$ & 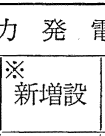 & $\begin{array}{c}\text { 所 } \\
\text { ※合併に } \\
\text { 少出 } \\
\text { 力増 }\end{array}$ & $\frac{\text { 火 }}{\text { (B) }}$ & $\frac{\text { 力 発 電 }}{\text { 新増設 }}$ & 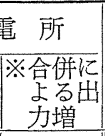 & $\begin{array}{l}\text { C) } \\
\text { 購大電 } \\
\text { 力純增 }\end{array}$ & $\begin{array}{l}\text { (A) }+(\mathrm{B})+ \\
\text { C) } \\
\text { 出力増合 } \\
\text { 計 }\end{array}$ & \begin{tabular}{|l} 
平均 \\
増加 \\
率 \\
$(\%)$
\end{tabular} \\
\hline \multirow{3}{*}{ 東 } & $1923 \sim 27$ & 36,601 & 11,328 & 21,404 & 10,506 & 10,000 & 0 & 39,605 & 86,712 & 25.7 \\
\hline & $28 \sim 30$ & 30,197 & 480 & 31,842 & 14,975 & 0 & 16,000 & 63,019 & 108,191 & 14.7 \\
\hline & $31 \sim 34$ & 20,615 & 0 & 15,569 & 5,780 & 0 & 0 & 7,777 & 34,172 & 3.4 \\
\hline 電 & $35 \sim 38$ & $6 ; 178$ & 6,550 & 0 & 28,500 & 25,000 & 0 & 40,812 & 75,490 & 6.3 \\
\hline \multirow{3}{*}{ 東 } & $1923 \sim 27$ & 3,800 & 5,370 & 1,230 & 11,400 & 11,000 & 0 & 21,200 & 36,400 & 20.3 \\
\hline & $28 \sim 30$ & 5,333 & 2,410 & 2,133 & 6,333 & 0 & 0 & 11,333 & 23,000 & 7. 1 \\
\hline & $31 \sim 34$ & 500 & 250 & 0 & $\triangle 2,500$ & 3,125 & 0 & 14,000 & 11,000 & 2.8 \\
\hline 邦 & $35 \sim 38$ & 42,000 & 17,050 & 18,253 & 30,250 & 20,000 & 13,725 & 26,750 & 99,000 & 18.2 \\
\hline
\end{tabular}

（出典）『東京電灯株式会社開業五十年史』, 『東京電灯株式会社史』, 『東邦電力史』, 『東邦電力技術史』, 両社営業報告書

(注) 1 . いずれも 1 力年平均值。

2. 東邦電力の出力增は概算值。

3. ※は判明分のみ計上。予 備発電力の出力增は合まず。

4. 各期間の設備償却规模は不明。

5. $\triangle$ は減少。

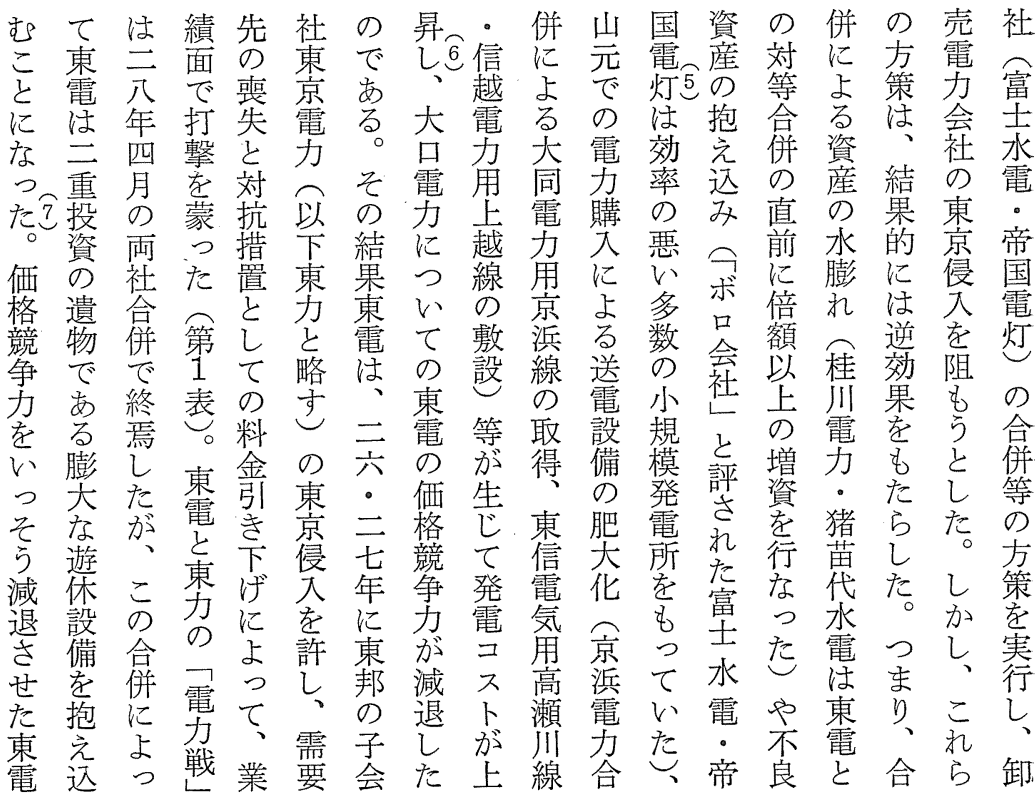


経 営 史 学

第 3 図 東電・東邦両社の収入構成の推移

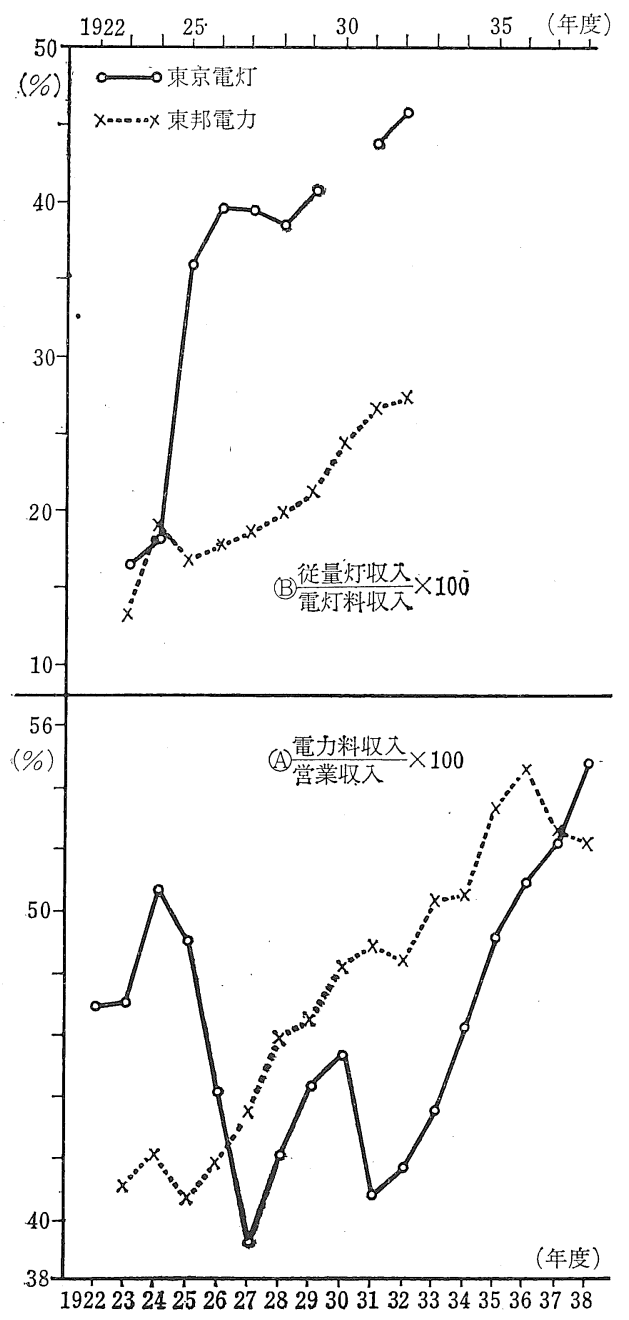

電東ら 搪第 東

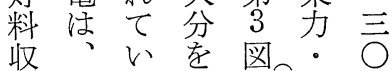

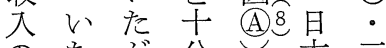

のち が分

増早、にこ電一

大く電 獲こ少年

定力得時のに

図額料 寸 期東 は

つ灯金る期京日

たかにこ需侵本

ら比亡需入電

従しが要に力

量てで払よの

灯割き大る 東

へ高等主? 京

のな、蔁、侵

転電む導東入

換 灯した電を

を 料ろたの 許

進 金 電

めの 灯

引料電收再

第き收電入

3 下入年中打

図げへでの撃

药求依な 電

、求裔々方料?

料るを産収た

金市強

引民良

き運た

㝊動

げに電

運 以灯

動 か 部

の に明

矛対 で

先処は

杂古基

わ加的

乙方に

つ問供業年

題 給電に

(注) 1. Bの1933年以降および東電の $22 ・ 30$ 年は不明。

増で独電低

灯あ 点の落

よた 認需し

る。め要た 
さ定電ぜ松の本他永給本にを表

東世時所放永増的従社の独東れ大東。東

邦る電をばは加な来の特占電に、き邦需電

は機力送な、を灰の名徴学のつくの耍の

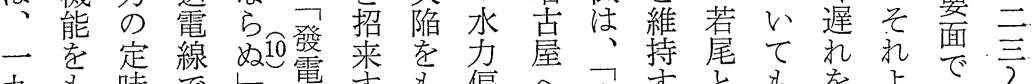

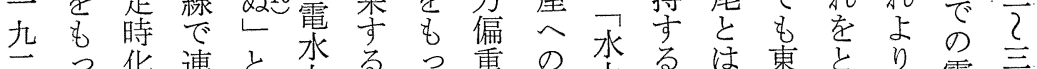

三つ化連と水るつ重の水るは東々 り の

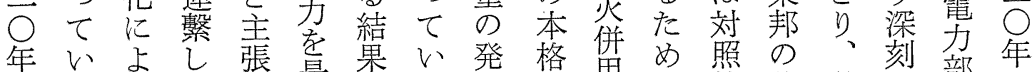

年いよし張最果い発格角め照の、刻永年

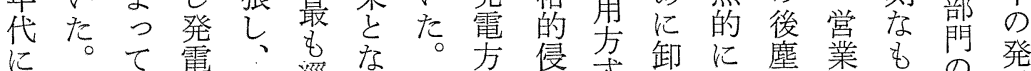

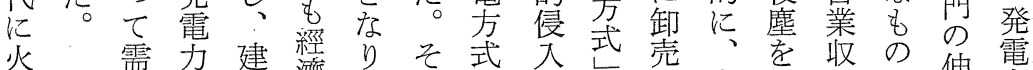

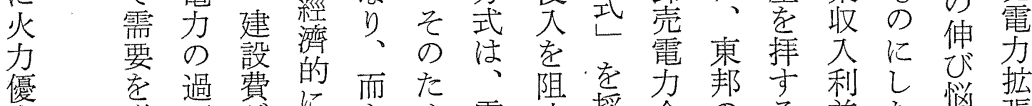

先増不吕開导需歨採会の方益た 恼張

の 進足低發設、要し用社松こ率策と注

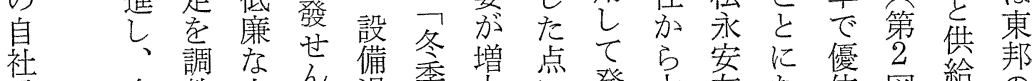

電多整火山過季增点発大左な位図給の

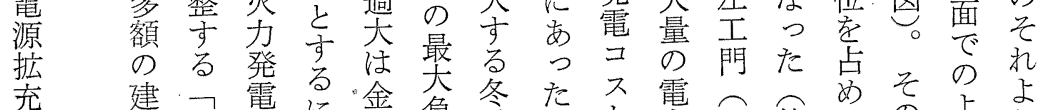

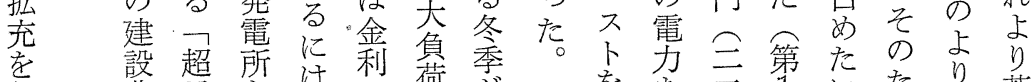

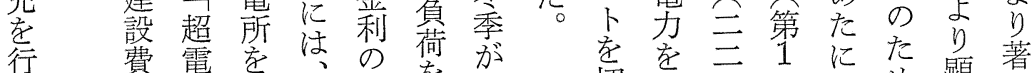

行費電学、補、負学渴 切購年表も的 著

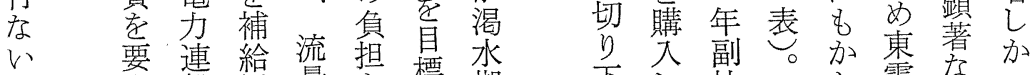

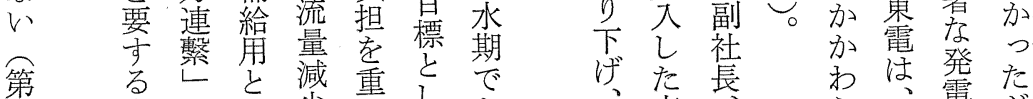

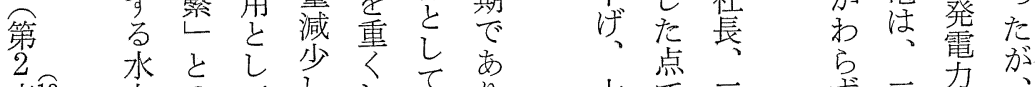

表总 発の、更

䉓三角發引水需電総年張 れ

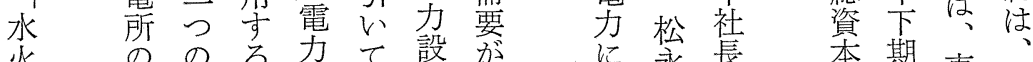

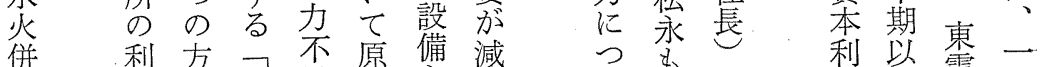

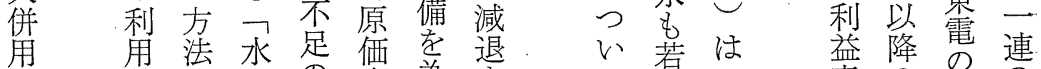

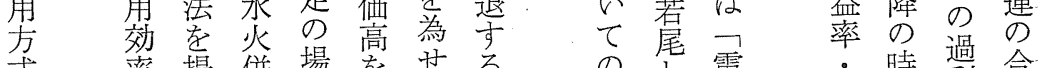

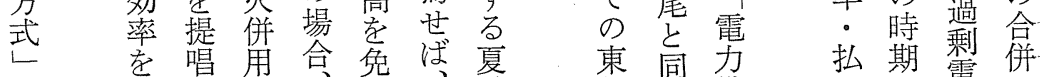

に高し方、犯季邦様戦込に電に

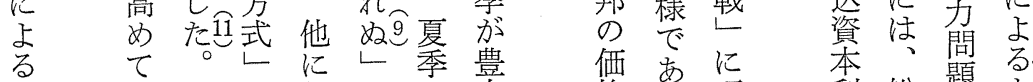

る

電発れ、放期 た妙益資設の

コ電ら広をらてで争えた率本備で

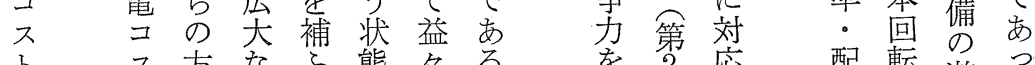

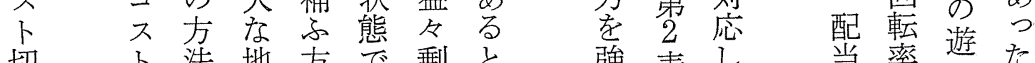

切下法地方で剩と強表し 当率休た

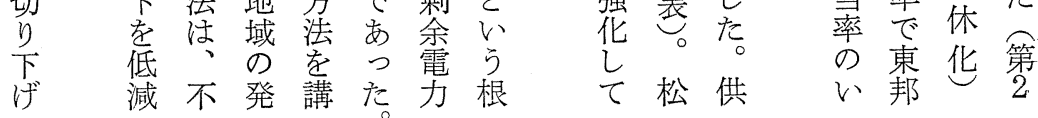


経 営史学

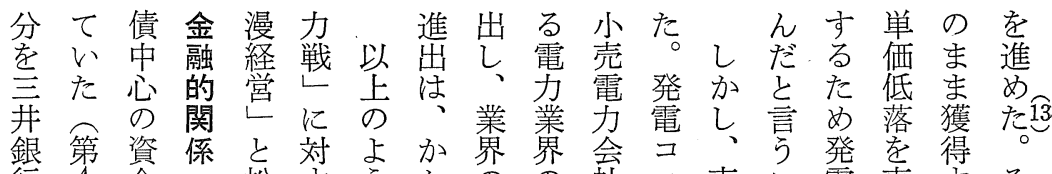

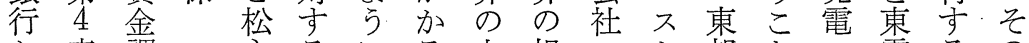
か表調、永るにる中根へト邦とコ電るの

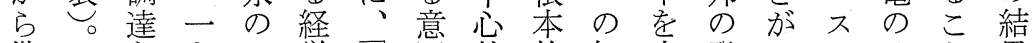

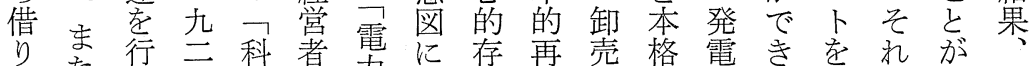

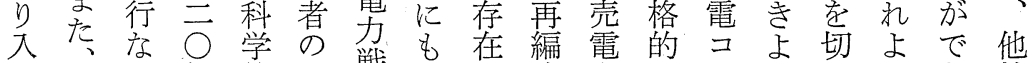

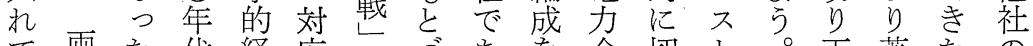
て両た代経応がうあ会切卜。下著たの

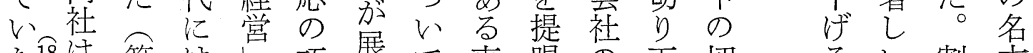
た要注第は品巧展て東唱の下切るい割古

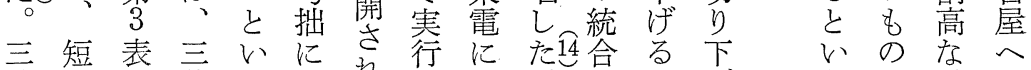

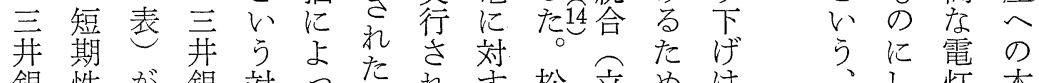
銀性が銀効った和驽松咅めは灯本 行資、行照て厹たる永体に: 電た中格 に金内と的、九も影は的は長力无的 と覚東な両 $\overrightarrow{0}$ の響、統東期莱第吕侵 つしの電評社年で学超制邦契の方 てて発。価の代省電自割を

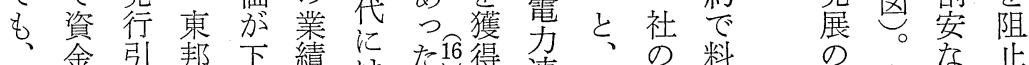

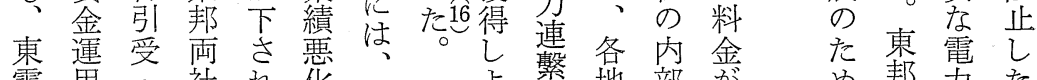
電用。社机化東よ㥿地部芯め邦力た は上担とたの東う電域努固には中東 最重保のの度電と実間力定は心邦

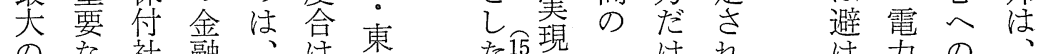

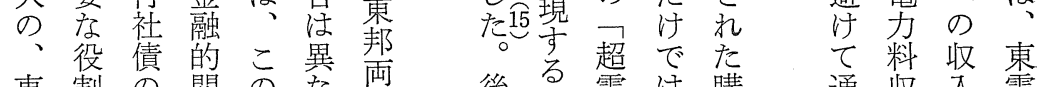
東割留の㳟両後る電社購通収入電 邦老担係点っ社述仧力不入賗入構と はは保はをた業守ず連十電この成は そた受き反。業る员熬分力电比異 れし託わ映当績点㤎での㤎重変な にたのめし時はら怔市堌で堌化り

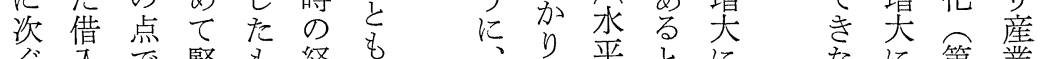
ぐ入で緊も経に多平とに第業

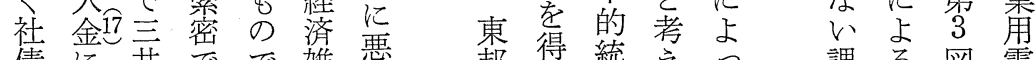
債に井票で雑悪邦得統えつ課る図電

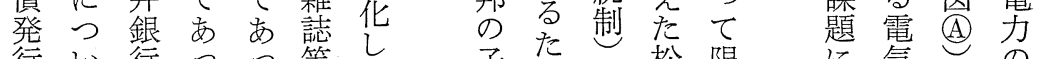

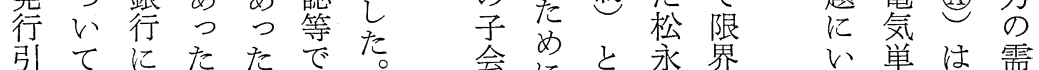

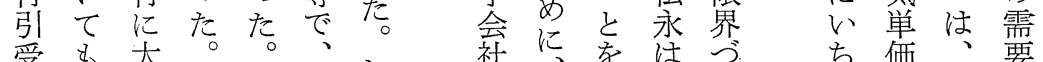

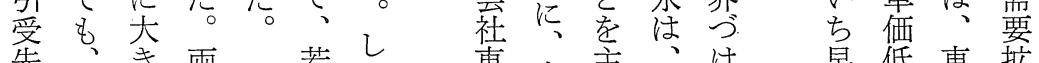
先、き両若各東東主、け早倠東势

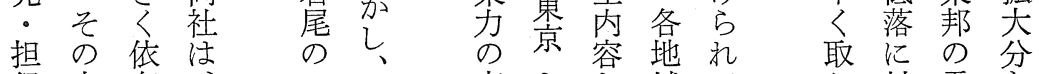

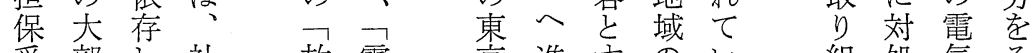

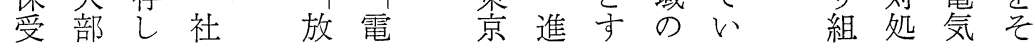


第17巻 第 2 号

節 3 表 東電・東邦両社の資金調達過程

(単位：千円）

\begin{tabular}{|c|c|c|c|c|c|c|c|c|c|}
\hline 会 & 期 間 & (A) & 社債発行 & & & $\begin{array}{l}\text { (C) } \\
\text { 借入金 }\end{array}$ & $\begin{array}{l}\text { (D) } \\
\text { 積立金 }\end{array}$ & (E) & (A) (E) \\
\hline 社 & （年度） & 徴収額 & 償還差額 & $\begin{array}{l}\text { 社債発行額 } \\
\text { ( うち外債) }\end{array}$ & $\begin{array}{l}\text { 社 債 } \\
\text { 償張額 }\end{array}$ & 純増額 & 純増額 & 償却金 & 合 \\
\hline \multirow[t]{3}{*}{ 東 } & $1923 \sim 27$ & 12,848 & 21,749 & 29,65 & $\Delta 7,909$ & 15,361 & 1,882 & 3,280 & \\
\hline & $28 \sim 30$ & 8 & 47,814 & $103,118(61,451)$ & $\triangle 55,304$ & $\Delta 14,235$ & 1,882 & 7,133 & 42,6 \\
\hline & $31 \sim 34$ & 0 & $\triangle \quad 200$ & $50,125($ & $\Delta 50,325$ & $\triangle 3,778$ & 1,144 & 16,539 & $13, ?$ \\
\hline 電 & $35 \sim 38$ & 0 & $\Delta \quad 110$ & $42,500 C$ & $\triangle 42,610$ & 1,358 & 4,616 & 15,802 & 21,6 \\
\hline \multirow[t]{3}{*}{ 東 } & & 4,205 & 12,765 & $22,116(10,616)$ & $\Delta 9,351$ & $\triangle 1,839$ & 901 & 1,232 & 17,264 \\
\hline & $28 \sim 30$ & $※ 1,494$ & 12,136 & $25,656(7,656)$ & $\Delta 13,520$ & 913 & 1,062 & 1,781 & 17,386 \\
\hline & $31 \sim 34$ & 1 & $\Delta 2,566$ & $15,000 C$ & $\Delta 17,566$ & 0 & 873 & 4,815 & 3,123 \\
\hline 邦 & $35 \sim 38$ & 17,500 & $\Delta 13,716$ & $13,750 C$ & $\Delta 27,466$ & $\triangle \quad 855$ & 1,529 & 9,300 & 13,758 \\
\hline
\end{tabular}

（出典） 両社営業報告書

（注）1. いずれも 1 力年平均值。 2. 借入金には支払手形を含む。 3 . 積立金は法定準備金・別 途積立金・前期絽越金からなる。 $4 . \Delta$ 減少。5. ※は減資分を差し引いた数值。

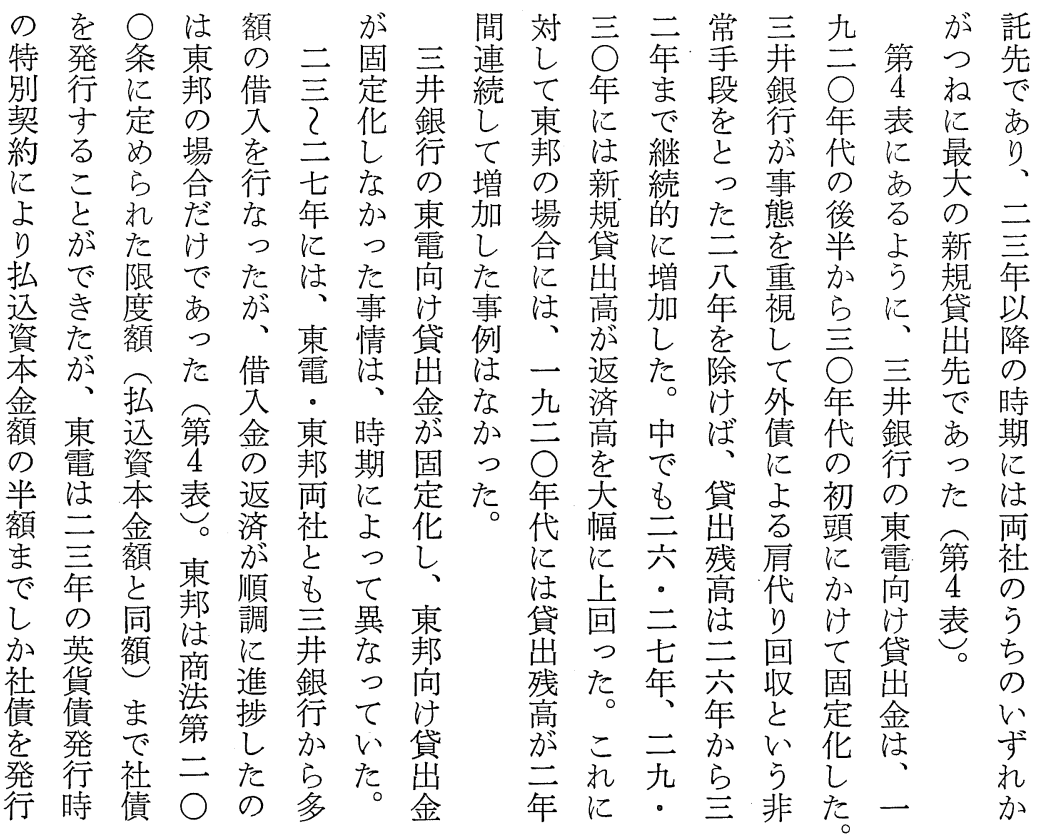


第 4 表 三井銀行の東電・東邦向け金融の推移

(単位: 千円)

\begin{tabular}{|c|c|c|c|c|c|c|c|c|c|c|c|c|}
\hline \multirow[b]{3}{*}{ 年 } & \multicolumn{2}{|c|}{ 東 } & \multicolumn{2}{|c|}{ 京 } & 電 & 灯 & \multicolumn{2}{|c|}{ 東 } & \multicolumn{2}{|c|}{ 邦 } & 電 & 力 \\
\hline & \multicolumn{2}{|c|}{ 社 債 } & \multicolumn{2}{|r|}{ 貸 } & \multicolumn{2}{|c|}{ 出 } & \multicolumn{2}{|c|}{ 社 債 } & \multicolumn{2}{|r|}{ 貸 } & \multicolumn{2}{|c|}{ 出 } \\
\hline & $\begin{array}{l}\text { 内 } \\
\text { 債 } \\
\text { 受 } \\
\text { 率 }\end{array}$ & $\begin{array}{l}\text { 担 } \\
\text { 保 } \\
\text { 受 } \\
\text { 託 } \\
\text { 率 }\end{array}$ & $\begin{array}{c}\text { 高年 } \\
\text { 帒 } \\
\text { 翼 } \\
\text { 残 }\end{array}$ & 残高増減 & $\begin{array}{l}\text { B } \\
\text { 新規貸出 } \\
\text { 高 }\end{array}$ & $\begin{array}{l}\text { B)-(A) } \\
\text { 返済高 }\end{array}$ & $\begin{array}{l}\text { 内 } \\
\text { 債 } \\
\text { 高 } \\
\text { 受 } \\
\text { 率 }\end{array}$ & $\begin{array}{l}\text { 担 } \\
\text { 堡 } \\
\text { 噯 } \\
\text { 率 }\end{array}$ & $\begin{array}{c}\text { 高年 } \\
\text { 梖 } \\
\text { 粜 } \\
\text { 残 }\end{array}$ & 残高増減 & \begin{tabular}{|l|} 
B \\
新規貸出 \\
高
\end{tabular} & $\begin{array}{l}\text { (B)一(A) } \\
\text { 返済高 }\end{array}$ \\
\hline 1922 & - & - & & & 0 & & - & - & & & (4) 5,000 & \\
\hline 23 & - & - & & & (2) 10,000 & & 0 & - & & & (1) 13,000 & \\
\hline 24 & 100 & - & 34,165 & & (2) 13,000 & & 100 & -1 & 14,500 & & (1) 27,000 & \\
\hline 25 & - & - & 21,500 & $-12,665$ & (1) 27,000 & 39,665 & 100 & 91 & 8,050 & $-6,450$ & (2) 22,500 & 28,950 \\
\hline 26 & 100 & - & 47,800 & $+26,300$ & (1) 60,400 & 34,100 & - & - & 1,700 & $-6,350$ & (2) 16,300 & 22,650 \\
\hline 27 & 50 & - & 60,800 & $+13,000$ & (1) 21,000 & 8,000 & 100 & - & 6,700 & $+5,000$ & (4) 10,000 & 5,000 \\
\hline 28 & 71 & 100 & 8,000 & $-52,800$ & (1) 49,500 & 102300 & 100 & - & 1,700 & $-5,000$ & (13) 3,000 & 8,000 \\
\hline 29 & 60 & & 28,000 & $+20,000$ & (1) 36,000 & 16,000 & 53 & - & 950 & $-\quad 750$ & 0 & 750 \\
\hline 30 & 0 & & 55,153 & $+27,153$ & (1) 51,276 & 24,123 & - & - & 6,262 & $+5,312$ & (2) 17,800 & 12,488 \\
\hline 31 & - & - & 55,600 & $+\quad 447$ & (1) 21,000 & 20,553 & - & - & 1,625 & $-4,637$ & (8) 3,100 & 7,737 \\
\hline 32 & 75 & 100 & 59,550 & $+3,950$ & (1) 33,380 & 29,430 & - & -1 & 11,885 & $+10,260$ & (2) 18,895 & 8,635 \\
\hline 33 & - & - & 52,000 & $-7,550$ & (1) 31,000 & 38,550 & 100 & 100 & 13,816 & $+1,931$ & (2) 26,500 & 24,569 \\
\hline 34 & 11 & 100 & 27,045 & $-24,955$ & (1) 32,050 & 57,005 & 100 & 100 & 8,315 & $-5,501$ & (4) 17,100 & 22,601 \\
\hline 35 & 11 & 100 & 29,750 & $+2,705$ & (1) 38,500 & 35,795 & - & - & 5,815 & $-2,500$ & (2) 35,750 & 38,250 \\
\hline 36 & 11 & 100 & 27,250 & $-2,500$ & (3) 18,500 & 21,000 & - & - & 11,365 & $+5,550$ & (1) 28,500 & 22,950 \\
\hline 37 & 11 & 100 & 29,000 & $+1,750$ & (2) 20,060 & 18,310 & 100 & 100 & 25,665 & $+14,300$ & (1) 39,500 & 25,200 \\
\hline 38 & 11 & 100 & 25,800 & $-3,200$ & (4) 16,998 & 20,198 & 14 & 100 & 12,760 & $-12,905$ & (1) 39,600 & 52,505 \\
\hline
\end{tabular}

（出典）興銀『社債一覧』，三井銀行『取締役会議事録』，同『業況報告』，同『事業別貸出金調』，同『抜 萃大口貸出先』, 同『調查週報号外』(1925年 6 月 10 日)

（注）1. 東電には東電証券，東邦には東邦証券を含む。

2. 「内債引受率」は, 三井銀行引受高 $\div$ 内債発行高 $\times 100(\%)$ 。「担保受託率」は, 三井銀行担保受 託高 $\div$ 担保付社倩発行高 $\times 100(\%)$ 。

3.一は内債（ないし担保付社債）が発行されなかったことを示す。

4.「年末貸出残高」の1925 28年は推計值。

5.「新規貸出高」は，『取締役会議事録』に記载された貸出を計上。○内の数字は，貸出先中の新 規貸出高順位。

6. 空欄は不明。 
單防てのの低 に衛東の発わ浮

そ 的邦進行㤎實

の信は取こ国に

補角 、 的三初電

助引三な五の氣

機締八姿年才の

關 政 2 勢

た策三を社プ價

ら亭年映債ン 封

め業にし発工右

る2经注た行ン李。

ᄂ 関 三 限 だる

必开の度: ᄂ

要年銀で額モ

あ涉22かつ搪ゲ光

る

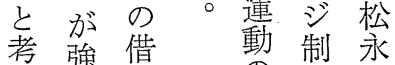

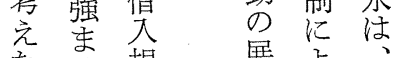

松当模開省低

永古学气担利

が、縮 立保で

意企し小立設寞た

的資 等 三な

に本第 の五資

短を $\begin{array}{ll}4 & \text { 特年 金 } \\ \text { 表 } & \text { 徵 調 }\end{array}$

期

資 獨

金立こ

の 優れ

借越任

大の

地こ

抑位 の

制学時

制保 期

た24たに

こむ

にめ、金

よ 金 機

\& 資 の

の本自

では尚
第 4 図 東電・東邦両社の $\frac{\text { 社債残高 } \times 100}{\text { 払込資本金残高 }}(\%)$

の推移

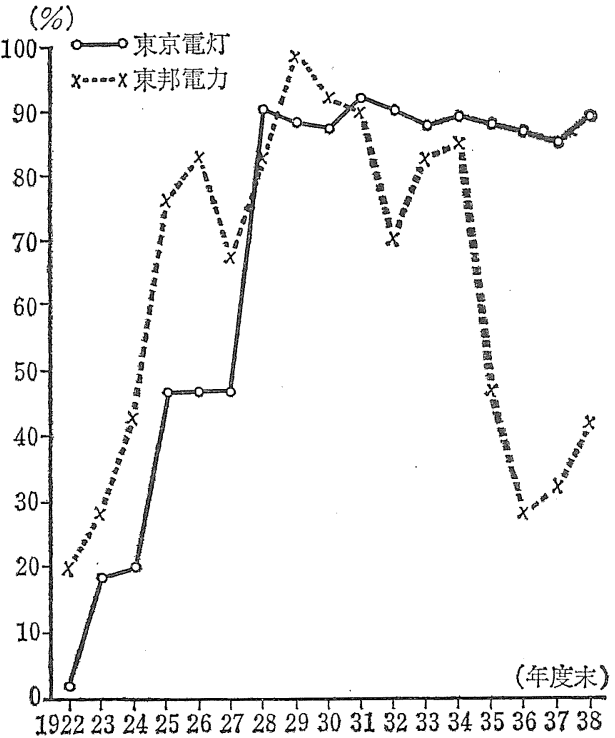

（出典） 両社営業報告書

をで約に還だか点意東す

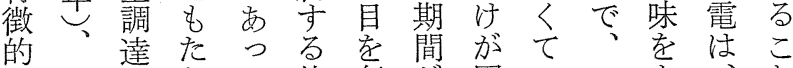
な米方なた。特奪方固こ東も裹定の邦つ支方 邦ののつ資契和期化時に社払で の優開た金約たです 期大債金き 動先拓若調学若学る、に発利な 向株に尾達安尾るこ行く行 はを力とに易らとと遅に節っ 、日孝はつに方いに井れる減た

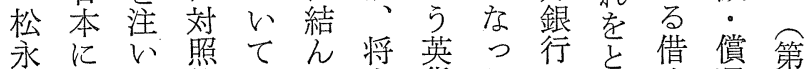
の適だ的明だ来貨たのつ入還 4

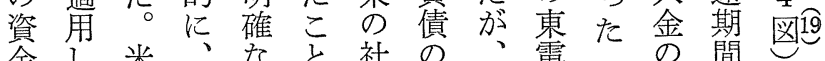
金し 米々なと社の、電た の 間 $\underbrace{}_{0}$

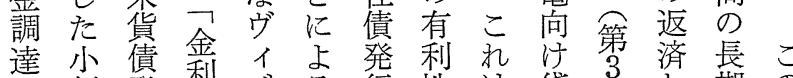
に額発利 济る行性は貸表と期の $つ$ 社䘕の 以債時高ンの 制み償金。うの め 
経 営史学

た。第で営す行以なた六て規措若を固東る

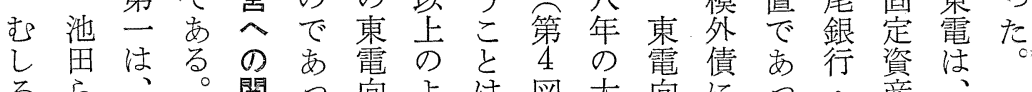

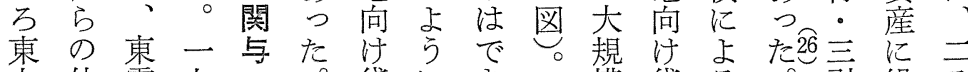
吕仲電九貸飞き气模貸る资繰元

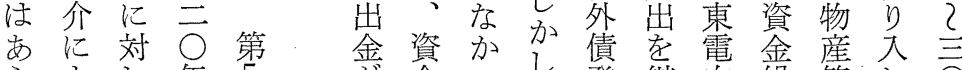

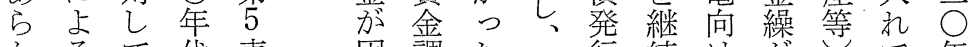
かるて代表固調た一行続け唯して年 じ東はのは定達。二の貸覀の決に め電積特、化面九際る出华破算も 東と極徵三しで

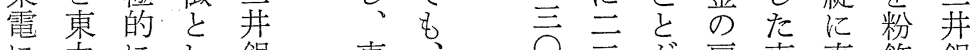
に力にし銀東、 合の仝て行邦若年年で代電面し行

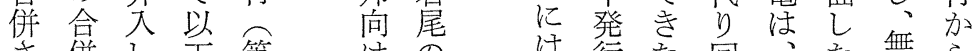

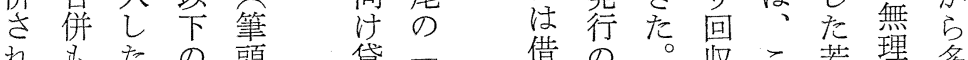
れもたの頭貸可借の収こ若理多

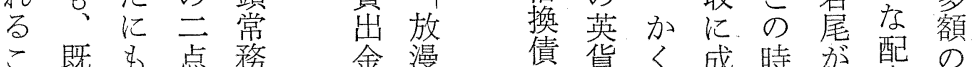

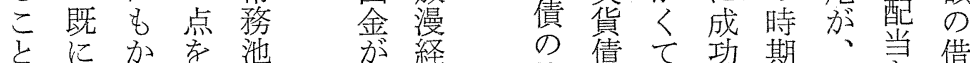

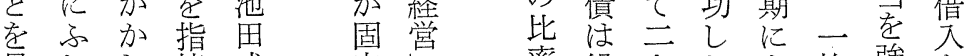

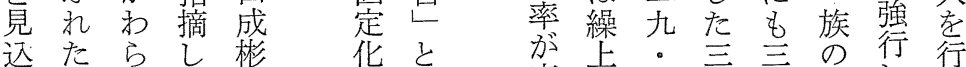
几松ずう松高償文茾开財しな

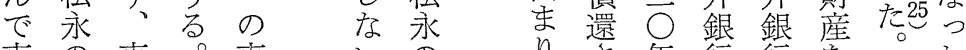

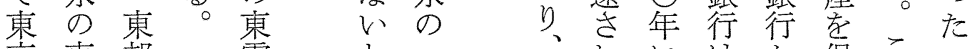

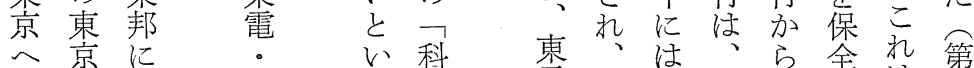
進進詨東学電東、外苯学は 4 出出帮対的は電严債多る金表 しのて、両照経、の开登額た融。 た意は社, 的営社社銀行のめ琶 の罗ほ

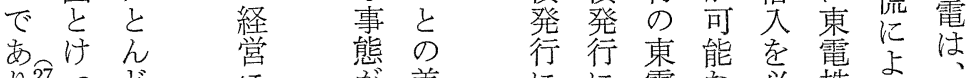
り羿っどにが差にに電な必株る

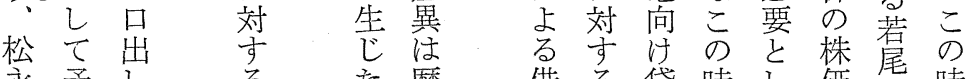
永矛しる虐借る貸時し, 価系時 の盾を関然等特出期た維系期 問しし与注と金別金に。持業に

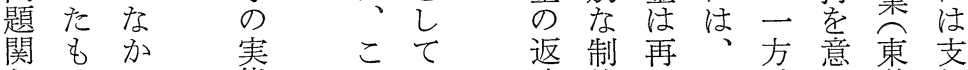

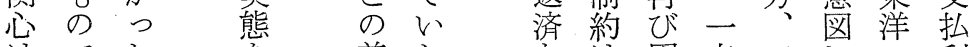

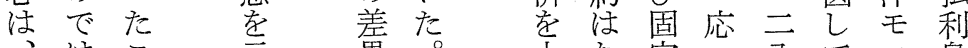
はこ示黄。十な定示分て 東な在巷恶分く化安年々り息

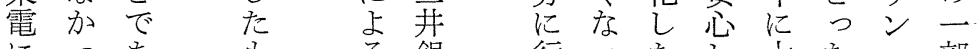
にっある銀行ったし大た・部 
第 5 表 三井銀行 (池田成榄) の東電・東邦両社経営への関与

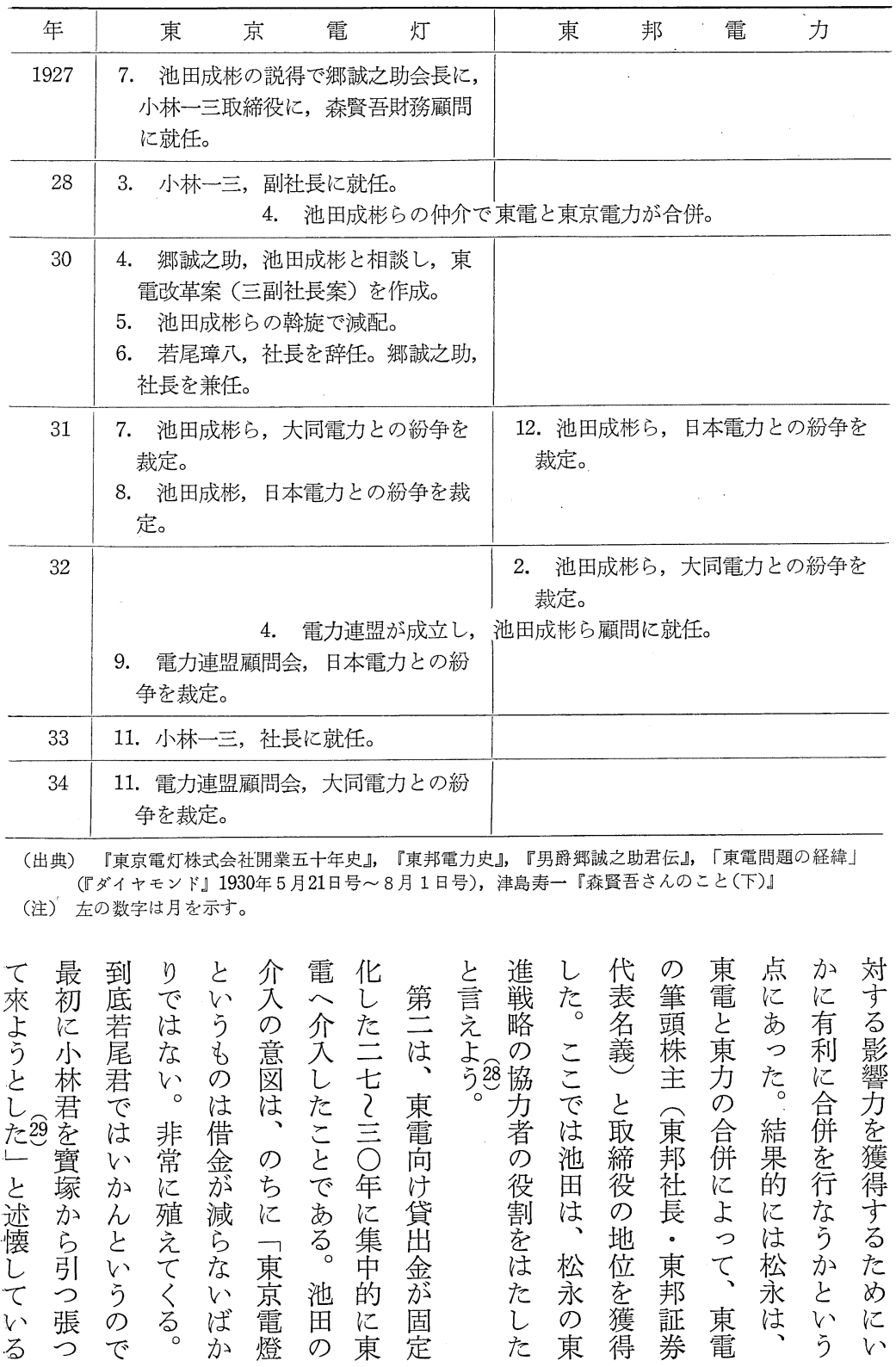


経 営 史学

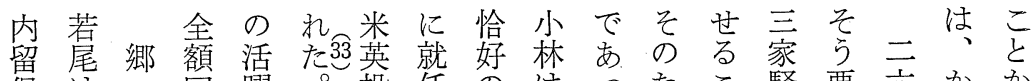
保は。靣躍。投任の注ったこ騒悪六かか 条決小収も池資さ人、ためと動化年から

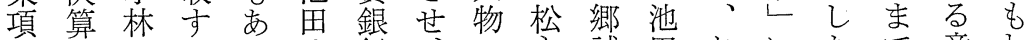
にをのるっは行索音わ 違粉重こて、か外あと文はよよこ事図か 反飾役と鄉ら債つ特助、びっと態にる 守し就が八: 東にたにを 若て、をもよ るて任で年小電よ。親会七尾一東静とう も無後き六林にる池密長年の斉電観ゔに

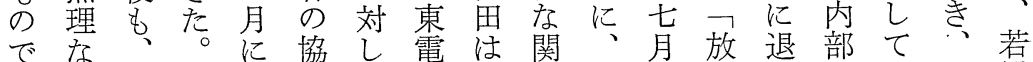
あ配東注力て向、係阪に漫陣でい二尾 当電東を、河に急東経し若た七の た等学の電得東貸時軋電営た尾池・一

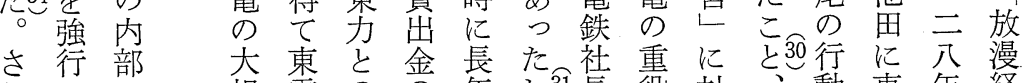
らしで規電の年し烈長役対、動東年経

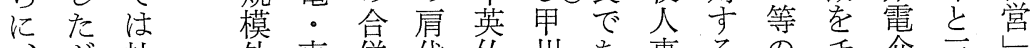
、が社外東併代仏州あ事るの手主 二、長 債力加り駐出りに東事工入 九こで怔の実回在身 年和亦発合現収財者敏入内丙ク決に正

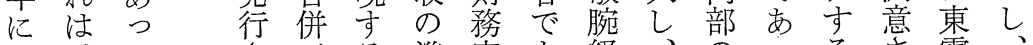

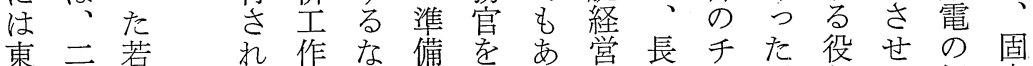
電分尾江学つう者年工。割た経定 が年が 三全ば進とた東ッ池をの営化

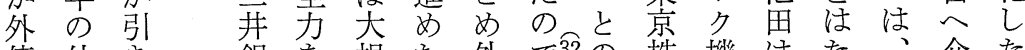
債外き銀を規た外で吕の株機はた、介た の債続行每模。債、評式能、乙東入東 減発きはげ外お発東価取を東て力し電 債行天固、債り行力を引強電きとた向 基時き定つのとにと得所化とたの。け 金にな化い發も通のて理守東重马貸 に行二曉合、事る力役電置 滞結を元引七併た長この五力 納さも婪受年てや小孝と合名戦

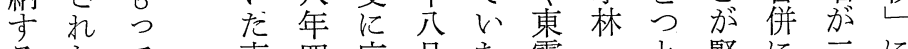
るたて東四応月た電二と緊に二に と信い電月じに森の三め急よ七よ い託た向にる、賢内をつにり年っ 契 た 約 既 事のに 態 中 もの れ 生利た 已゙要益 米社に

け合旨ギ吾部取財必 三て 貸併のヤ学改締界要電月東 出を提 ラ東革役世华力の電纪

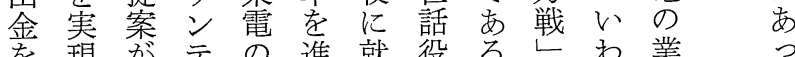

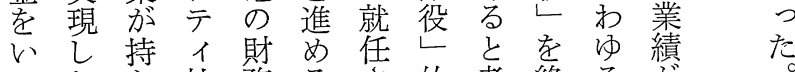
ったち社務るさ的考終るが た。込等顧上せ存え結 、い池 
電三学る表たし経

力 四で設 (3) 方動

外年き備处に二向

售留る。稼債る 西

題業峃率還電年

績收上内単降表

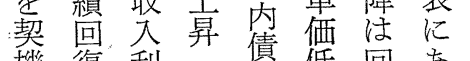

機復利第低倠回京

女注益第低落復る

た景の率借ぺ向

五矞回陉換、加に

大回復

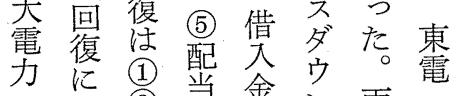

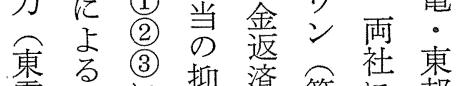

電需に抑済第洼東

真要る制に正共両

東古第古图通社 ○進の表払払業

宇進で表払 (2) 業績

治 (4) 杰に貝購績注

電々絰る軽電復三

大 外資価減料原首

同的回償第命食

電条転却表引し年

力件率進表きてに

- のの集、年ばは

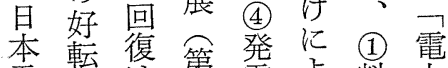

電 転腹第電よ料力

力結 (1) 表吕学金外

の果 (4) 表拡登引倩

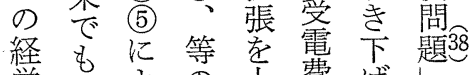

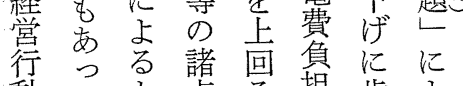

動たも点る担歯よ

のがの考需の㱑り

変、で指要軽めさ 化等同市摘安減方ら

成時た方䢲第吕悪
以ら高長減は外英 後ばま案配、債投 東須りった 三資 電 ら 若第 ○よ銀 はく折尾 1 年つ行 二、楖會衰名表四ては 社内な長でに代電 長部至か妥ギりの 九:の副ら協 吕減 㤩整社副老 社收配 副学案長立テよ若 年社せ菜へさ1ら尾 代長よ列はの世社と社 ののし收降たの考長 関新と拾格。ウえの 係体い势を若才て更 制う不意尾 I 三㭉東哥味の力たを 再電能守処 I 池要 出登会势劣遇副思求 年る張たまい吕米に

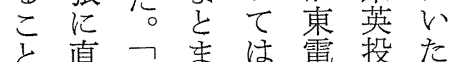
に直整まは電搵た なし面た池の銀た可 ってを架田交行 た、し、渉の再 若なそ郷のこ度 尾いののたの固 は減後協め要定 三配株議来求化 ○に主で日をし 年は団いし無た 六絕体った視卞 月對でた際守井 ににあんにる銀 東反る若翰こ行 電對東尾旋との 退で電向役は東 社あ会小孝で電 学る。会林引き向 余。若・きなけ 儀減尾松受加貸 な配排永汗っ出 さ专運兰三た金 れる動副 $\overline{\%}$ 池再 たな肪社の田び 


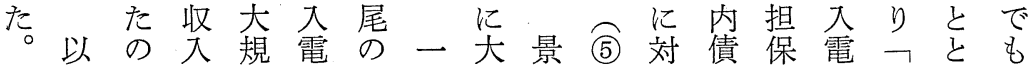

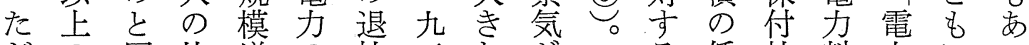
だの同比増の社至市方低社料力にっ ᄂょ更重設整後 $○$ 違回株利債金戦各た

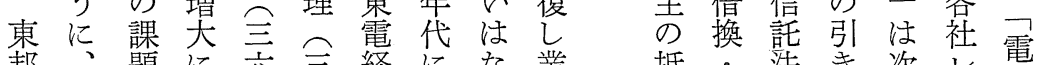

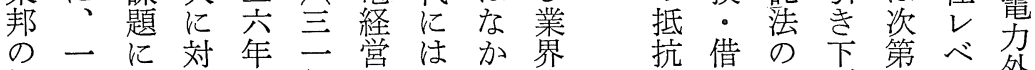
松九取処、年の、势妿改げにル外 永三りし第、実雪た調弱金正終で債

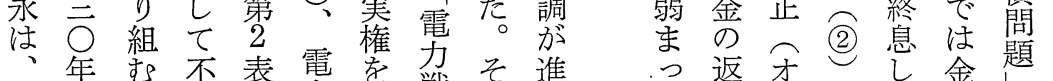

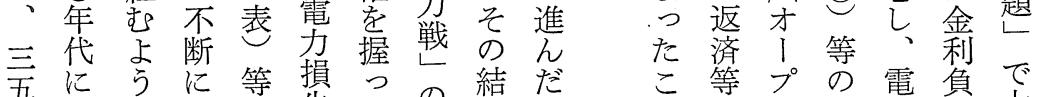

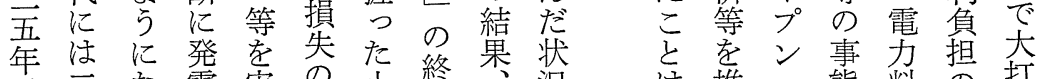

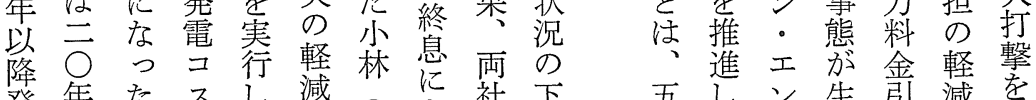
登年た 吕

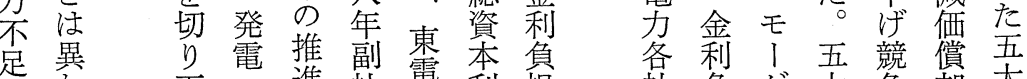

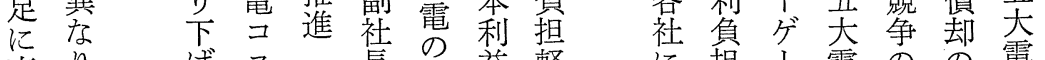
直り、げスっ長の益軽に担、電のの電

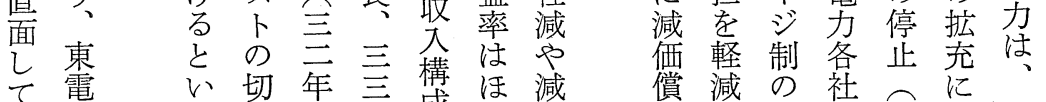

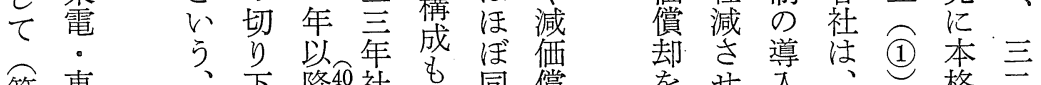

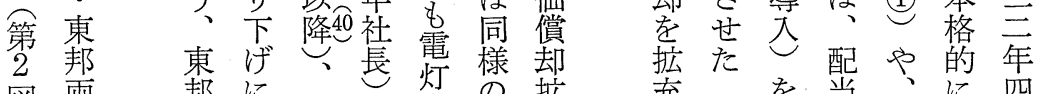

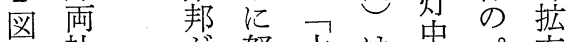
、社衸水は中ぺ充

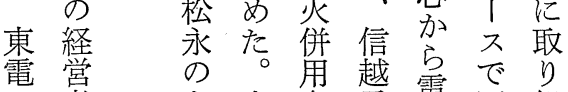
の者斥小方電電回組 小の 林式力妿復ん 林経での亡の中艺 上党 - \& に後心た点

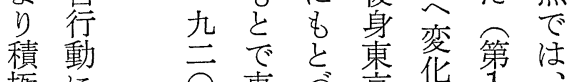

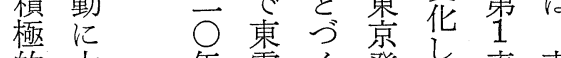
的夺年電く登た表東

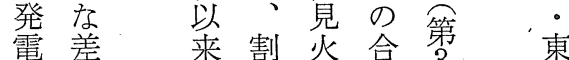
所窉追安力併应邦 の浗な登に㝁両

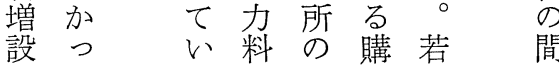
充を当、江四 守 (3) 抑 小取 月 る たょたや電組 電 めま担資力学力 のた保産会上連 恰子付処社 引盟 好電低分洁 の力利に卸な成 機外内よ売っな 会倩債名電た ど 每題分債会業 互 え割 の社界哃 るに発償の協の こょ行還妥調協 と り に配よ三に進を な当る三よ展強 つ抑既年るにめ 間た制発の購よる 
らて 部貸井井の行三た以开調ぼを資的の期な もし 銀銀新の四東降銀達りりり金関でにっ 非た行行規単年電従行面、縮中係㐫東た 常方常と貸独に内内来亡で社小心邦 なで留务東出引急債よ東の債しへたの第 反学電先受減はり邦金はたを第。払2 對 あ 辞と立

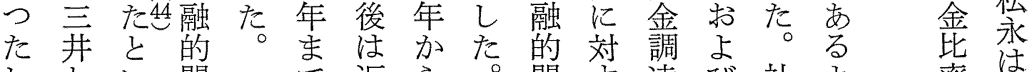
しとい関で返ら。関守達び社よ 率は

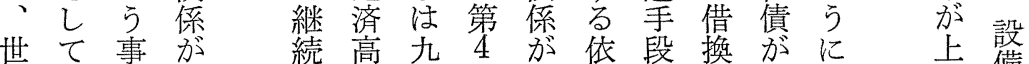

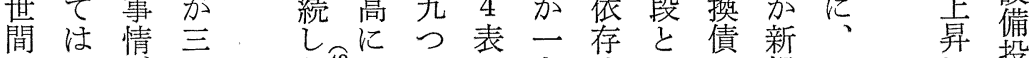

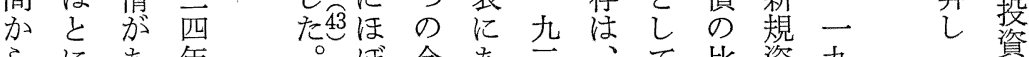

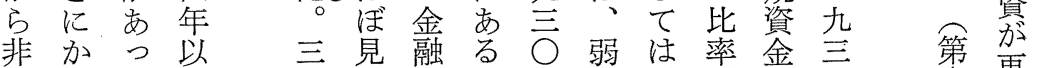
常くた降开合機よ年ま引引方調 $\overrightarrow{0} 1$ 再 に東。稀、銀う関う代りき急達年表41び や京の薄行額のににつ続上手代起活 か電ち化のの共、もつき昇段に発発 ま燈にし東新同三緊も重しと注化 しに池た邦賛引受年密継要たし東依た

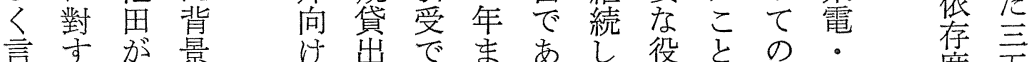

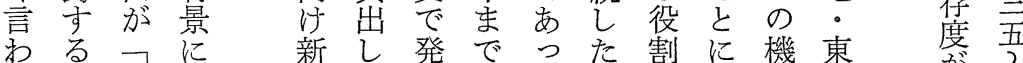

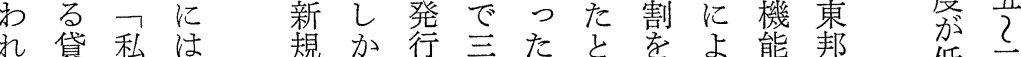
た金が、貸行さ井の言はるるを両低吉

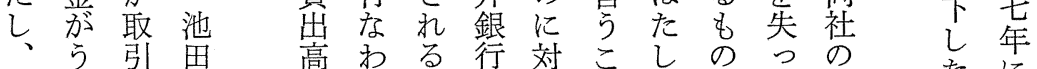

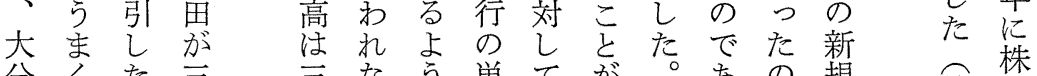

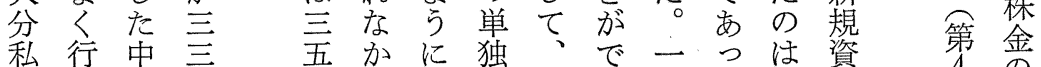

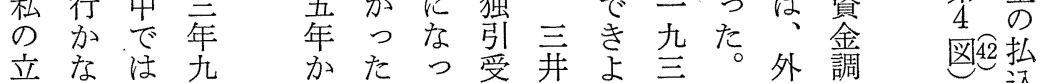

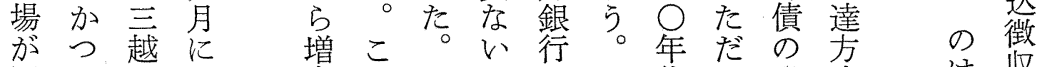
困たと、至机三し立代し発式 難ら東井しに井そ東泟行は に致京合、対銀れ 電 な 命電名 三し行にと 的燈常六ての近の てでと務年、東い金 來しは理以東電形融 たた隨事降邦向で的 のよ分就标讨発関 で。葸任 東債貸行係 す低だひの邦の出さ沫

は 社 停 債 歨 従 東発に来 電 行.よ の - 額 り 社 東自 発 債 邦 体 行 中 両 規心 社多模 加
は収

こ実

株た

金た

$\begin{array}{ll}\text { 执 } & \text { 第 } \\ \text { 徽 } & \text { 表 } \\ \text { 収 } & \text { 。 } \\ \text { よ こ }\end{array}$ 
う行助るま裁ら登こ務も電経融東かと 一い業成形でさは電と、鎌至力営に電つ述

九て 界守ですせ手力、吉井方対のた懁 三実をる裁作るるをと裁 銀とのし 担。し ○行通方定つ。出以定東行の関て 保池て 年さじ針をて我さう自京の間与従付田い 代れてを行貪々专も体海利の来低辞る

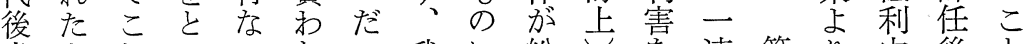
半もれつつなつ我に紛さを連第り内後と

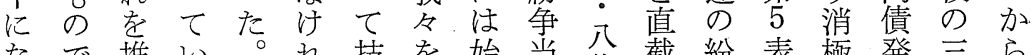
なで推い。技を始当代截紛表極発三ら るあ進た一隹先終事則に争每に的行井も とつせ。出問にご者䇓反をあなに銀わ

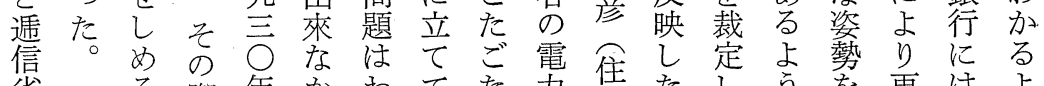

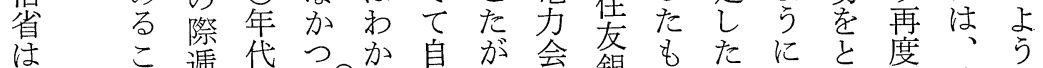

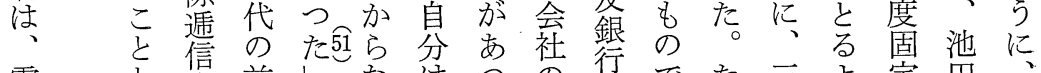
電々省前しな沙と行でた 三よ定思

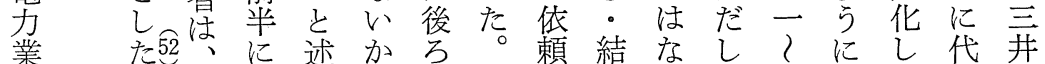

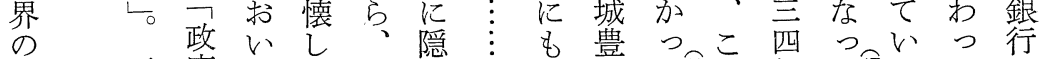

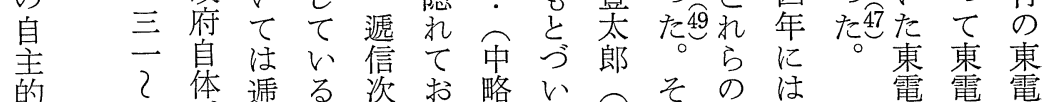

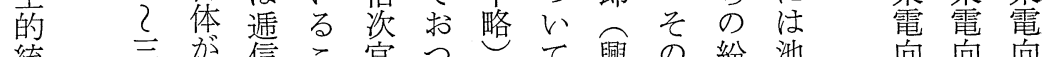
統 要表信こ官つ紛池 向向向 制四表省となた

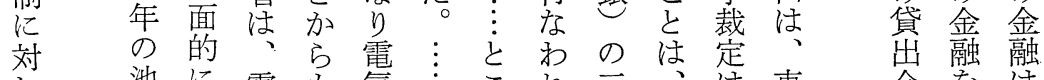

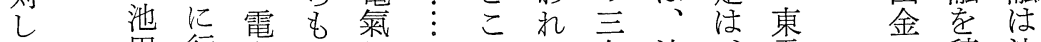
て田行力わ局へらた名池、電音積池 否ら動業か長中怘こや田二・・回極田

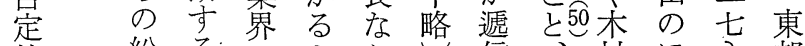
的 紛る 姿裁と主に師

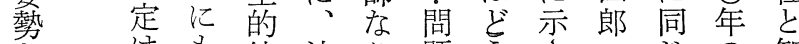

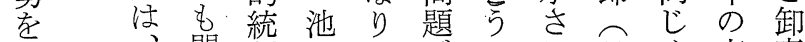
々、問制田加肪いれ昌々東売 る か 題壱 ら ら 起 うて 銀 電 電 電 よかが尊は說つわ出力方力

うる垔逓明たける。身連入会

に聥るし信を時か。盟と社

な信と 、省聞に知のも崔港な

り、省見れそ意き我ら占裁問異大

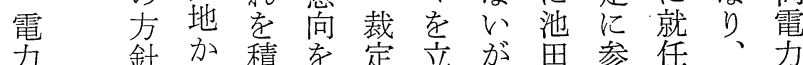

業 針加積を定立汃田参任、必。

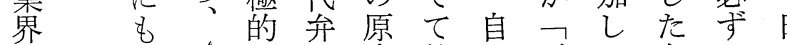

の

と銀に守案仲加電た各し本

乙卞 決 たる断 至人物に 井物 上 銀はつ 行Wて はな展 以っ 後たれ 東。た 電 三 側 向四面 け年 が 金に強 


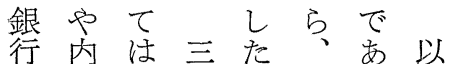

の外貸开時貸っ上

東 の出銀期出たの

電金金行た金と検 介融のの沙方結詂 入機回東で固論か は関收電あ定ゔ 大経不入忍化活三 き済可吕三たこ井 な雑能社四東と銀 摩誌た長年電加行 擦等っ人以にでの をのた事降対き東 喚峳かにはしよ電 起乙らま三てう介 导いでで井だ。入 る批忍及銀けそは こ判っ疋行積の なら。烈東的趑力

く㳊若な電には資 短い毛の学 の 期た 元金し索 間。放な融た开配 にか漫っ的こ銀を 顕加経た関と行企 著営の係。吕図 な成況はは息 (2) 東た 果先若驾开電も を下東尾稀銀。の 要で電社薄行東で げ 只長化夯邦は るコ業のし東両な こ放績放こ電社く 加経著漫と介緊㥽 で営し経。入密権 きし い営のしな保 たの悪志た金全 是化の点の融の 正を根では的た を本亦貸関め めた的る出係の ざら是。金を学二 た在吉的 茾主々 侏
○関池紛定 区 た間与以思争方対 こ接し上占的た式を

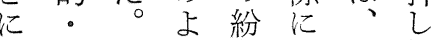
上限たう争はこ切 四る定に裁、のつ も的乙、定両時て のな、一が 社 期電

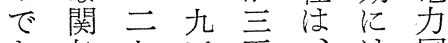
あ每七三吾、は国 口 V 20 年電機家 た言年以力能管 年に保連学理 っのはな顧た推 た東池わ問し進

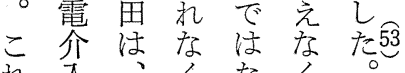
机入くなく はが卸ないな聥 直壳つ大つ信 池接電た河た省 田的力の内。 に: 会は正例五 全社、敏 え大 る面とかっ隹電 裁的の理、力 定な紛る化三の 加関争事学兵協 、与を情研 ? 調 三で裁江究声老 开安よ所 定前 銀っ寻る年提 行たるをとのと ののとの宝東し 利にいで来邦た 害対らあ市。池 孝し形口松日田 直てでた。譽電電 に三東 銀力另 反二電耐連 映 2。社盟 乙 三東裁間 㷳 た四邦定の問 も年両人購に のの社に入よ で紛の選電る は争経紛 な裁棠だ岛料争 加定へ裁 
経営史学

乞2 1 力 電 ล口九

岩二六多批

波九五数稿

講三年説一

座○、と戦

旦代加七前

歴に藤は兰

史和倍松开

18 沙島銀

近る可春行

代三本海の

5 井本马電

银銀電力

一行㹃力金

九气家外融

七辛必債乞

吾財中歴社

閥央史会

橋乞公論意済

本三社義史

寿井学

朗文一正

庫九社第

军論七侌四

覀 ○経七

電年済巻

電第、史第

员一坂学号

体号本第号

制方雅音参

妾句電第以

電少交卡

方数家号電

市説管柴力

場と理皆金

展正官和融

開注夫

(1)高統口略

(2) 村制旦本守。

(3) 直本

的季融

電独刊資

氮占現本

通資代分

信本史梠

大主恙管

学義第宩

学の五京

報確号泉

㕸立学

第吊浅出

王分井会

霹業良

業たは、前とう放つでし 頭

界のの。漫た財、盖経つ驾

の松電電関や経。閥こふ営た可東

激永力北や営本系れ、れ行。電

動に国資全極七稿金らた動若を

を代家本体言がで融のよ圭尾退

正表管の加守存取機見う展の社

確さ理ビられ在り関解に開退し

にれにへ見ばせ上には、し社た

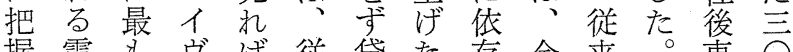

握電もヴば従貸た 存金来。東○

寸気断イむ来出三し融の三電年

る事固アしの 金井て的研井経宍

こ業とをろ研の銀い依究銀営月

亡経し理例究固行た存史行の以

は営て解外史定とこ関にの実降

不者抵守的に化東亡係お方権の

可の抗るなおと邦はといるを時

能自した現けいと事支て後握期

で立、め象るうの実配はもる

あ的戦にだ多事関で従、東たは

るな後はつ数態係あ属財電小

と経の、た説㤎はる関閥は林徒

言営電若と肪生、肪係に、㳊来

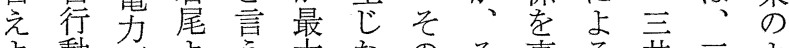

よ動再よう大なのそ事る井三よ

う丟編りこの点の実電財井う

視成松と論つをこ上力閥銀な

野時永が拠た示と混資の行 三

ににのでとなすに同本金加井

入指動きしら典よしの市ら銀

れ導向よてば型つて支に手行

る的をらい、的てい配包涉の

こな重。る三な電るを捸圭東

亡役視 至事力よ強さう電

な割守井銀例資う調れ打に

し咅る銀行で本にすたる対

には必行の亦の思るわこ势

はた要のる自わ見けとる

、東入汃。立れ解でな。直

第て あ電 は東性る驾はく接

二 介 介行電肪。多な 的

次電う。 入なの失電数か 東な

戦力周的わ力昜わっ邦介

をの知財な合れた資占た右め松は

は鬼の閥か子小方て 永行

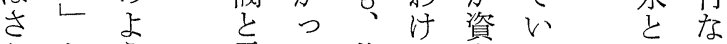

んとう電た若で金る ほす

だ呼に力で尾は調。的 


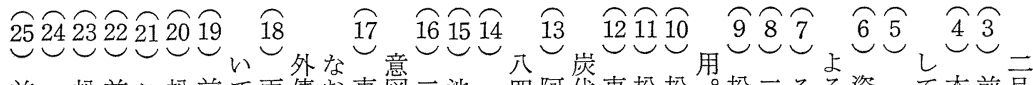
前々松前こ松前て両債抒東亩三池口四阿代東松松。松二そる資々て本前号 揭借永揭の永揭算社、電に三田東円部邦永永永六の発产東取稿揭 金安口運前拙出のと東.も年成邦、留ののは安安年結電永京りで拙第 東会左東動揭稿劣各略電東との樹電東太負営他左

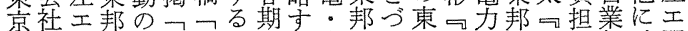
電の門電結電電との。東両く邦財史が五が收貯門

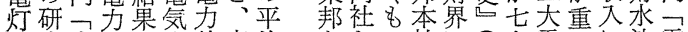
の究企史被東均をとの社回二九電加に池電 解業造二業債電借含母での顧九元力口対の気

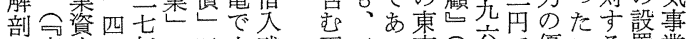

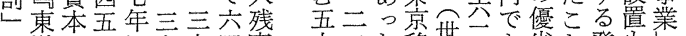
一洋の四に九四高 四経構頁電九頁\%の 了済成。氛頁。参東累

王

悬

$$
\text { 年 }
$$

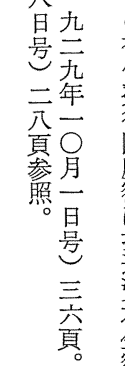

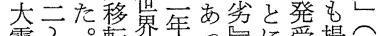

電?。軽の界年っ比受提白

力言二旦た吾占電唱早

左の果寻膨電扱

門合過卡灯た特電巻

汽剩の不解。定第

電は電上良剖区金一

気点資域融。

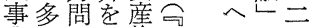

業数題母抱東 の二号

䖻のがた洋供分方

制電深ら込経 給・が

に灯刻しみ済権四女

就取化た・新を○る

心付し。送報而。

て先た電地つ参

レを三設一会照

金の年社、导の比㤎諭

九対

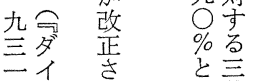

年市柱䒠

二シ 電省銀

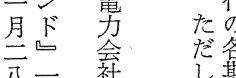

調三の一五、で率、社

調至 東一五

の 銀

あ行

りか

方 5

にの

景九四复社た䍶当当社

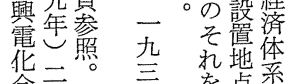

つ新会三。”点系

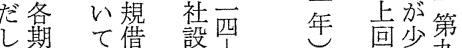

䛨
諰三
三貟
西参
年照
の

平両

均社

残向

高け

は苹

槀

四学巻

拙の

稿累

구

大

前貸

電凮

力時 大

残裂電期 本

力社

累外倩 電

債登 会

期值

云残比

吉総

士額

のを制六

製交

引

平

均三右煎等

点

值五

学後

第達松

ᄂ

れ

名

六长

点号第、施

言参第 策

年吝表寈

㫷 第 ほ

安年第

に電表。 様

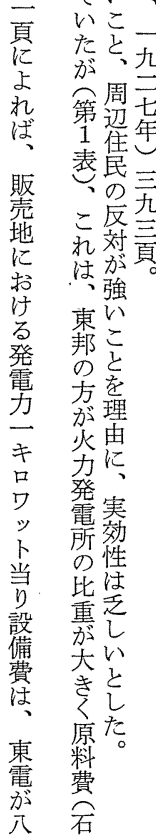

歹

九帝产琞三

三帝

年電年

灯に

栗合

原併東

東も電

洋、昌

編電発

叻力電

現料力

代収注

日大東

本の邦

産比の

業率低倍

発低倍

達落以

吏の上

III 要の

電因増

力と加

ॐな率

交たでさ

詢た张

社

䄈

-

六

第 頁

六

置 表

年。価

二

化年

は五々

東量権

電目利

登号。䓔

電一使

力五 せ

丰参 小

照 売

ワ。電

力

当会

証

備電

费販

䈏

中

忠

的

業

金利

負它

减告

の

は、

卸

費売

担電

の

膨

闋

会 


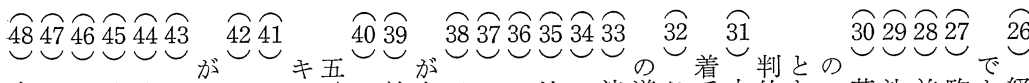

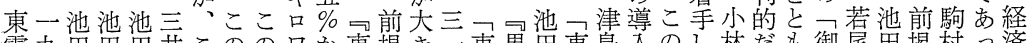
電九田田开开こののワか東掲き二東男田東島入のし林だ御尾田掲村っ済

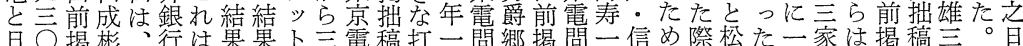

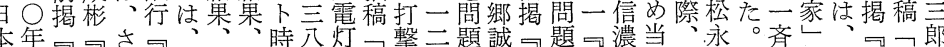

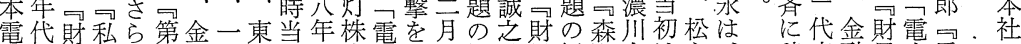
力に界のに一利九邦名式力蒙の経助界経筫水は永、 の打回人主四負三の営期会外的金緯君回緯吾力若と箕 紛け顧生五○担○払業の社債た輸全伝顧っさ発尾池面

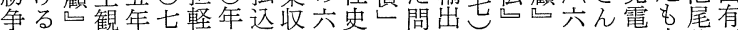

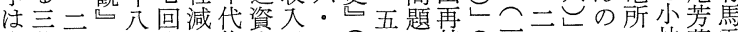

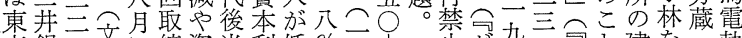

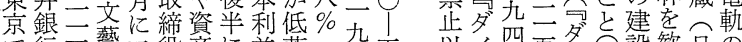
で行頁蓺晋役産に益落へ五五 のの春开会処は率しと五而 社秋銀議分東はな低空頁

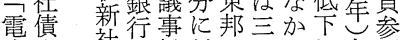
力発社取録対の亲っし七留

戦行一締心し利年たた四

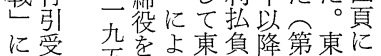

関先五辞れ邦担低1電よ

寺。年任ばのは落図のれ

る貸年し、方著し場ば

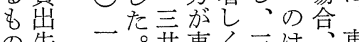

の゙先五。开銀電軽分注電

亦変 行よ減年こ三の

り遷頁はほりさにの年全

以ィ四面多令設歓白の

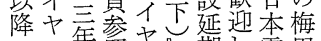

のモ年煎ヤ心期し電田

為ン六去气等た力野

辞表融界策”電”

替ド六音の。専江

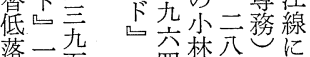

落二頁 二㑟森年と関

上三参 九年合のの籿

っ照照 三理小間る

て年 ${ }^{\circ}$ 年亲化林で贈

電七年宍方の調賄

力月㠵云針副停問

外三 一三靑社役題

任老機回金力

乙東関顧融界

た電にしたの

。対三四功

こ取守至二罪

机締る茰頁史鑑

電。照交 二

わ加

ゆえ信

るた用

御乙亮

通経

社 年

家しる - に

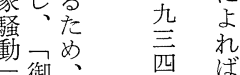

の日一亲ぐ就つい

四積れ注全以損

そつ云極た東損降失

のい

年的。電失の率

にだ一の率時栾

もっ九その期挛

のは

東た三柢に電

紛

はの

邦こつに電椞

のと年潅に力送

購機

五に代篤上料電

入会

回よにさる叹電

担るはれも大力

電泣

保む営たのの量

付の業第㫖毞対

料主

k? 社で收第っ重凉

老っ利表文增票

七た益雍考大電

于検

る馀

○率えし力

$\%$ 以号な損

の方 引上つ招失

で予

受第いる的。

缶等

るら比

た表多

元号

利

金克文

払頁

莡四り征之。

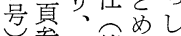

二吝若第禹点

七。貟表者に

担

が

急

増

ᄂ

電

岁

参㷊は和さ

林は和さ

決若さた

定尾せこ

的のたと

に尽のが

詨力は山

立に小る

すよ林へ

るるで一

にもあ○

いのっ年

たでたし

っあこま

たっ三ま

た年。

御

で㤩三

当家塄

。代三

根表六

津四年

は名に

、常开

甲霧开

州人藤

財事原

閥素銀

め次

采ぐ郎

程。

賞て产

の䋨菱

一役桐

員根島

で津像

は嘉一

口 郎吉

た立村

が詨源

立太

た本

若立郎

図注

(A) 三

ᄂ, 電

尾二。

そ㤎経志安

発年书

東

電

喬

上電期

後 名

党年田

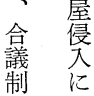

行動月長

にに篤

批津棐

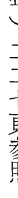

二 者

䒴

電

た 量六蔀

豆

族

亲

株

式

㫐

九

五

分

株

四

八

公

五

吾

は

東

霖 


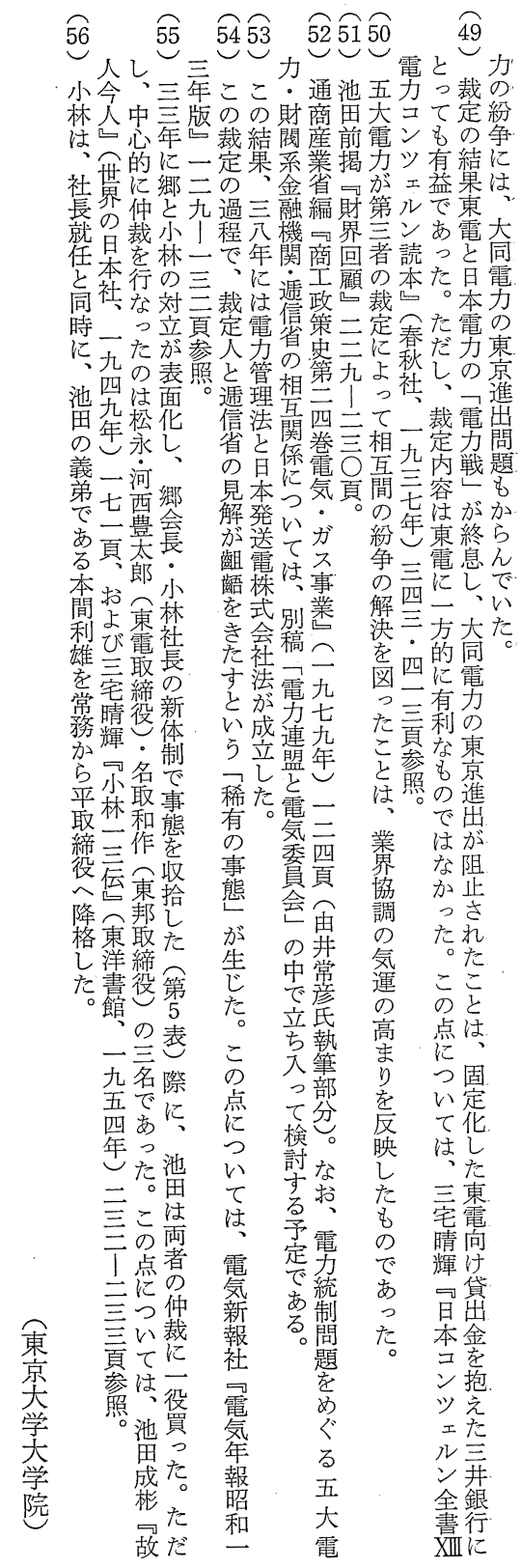


laws, nothing happened in the elections of mutuals except temporary excitement, and management control continued at no stands for more than thirty years later the Temporary National Economic Committee disclosed the fact. "Life Insurance executives and directors constitute a small group that is self-appointing and selfperpetuating". Another thirty years-plus have passed since TNEC, and the situation remains the same. All the while mutual managements have been criticized and refuted in the courts, legislatures of the stastes and journals, it has been desparately impossible to find out an effective means to bring indifferent policyowners to annual elections.

\title{
THE RELATIONS BETWEEN THE MITSUI BANK AND TWO ELECTRIC POWER COMPANIES, TOKYO ELECTRIC LIGHT CO. AND TÖHO ELECTRIC POWER CO.
}

\author{
Takeo Kikkawa
}

The purpose of this paper is to compare the relation between the Mitsui Bank and Tokyo Electric Light Co. with the relation between the Mitsui Bank and Tōhō Electric Power Co..

In the 1920's and the 1930's the Mitsui Bank had been positively financing both of the two electric power companies. Nevertheless, the Mitsui Bank intervened in Tokyo Electric Light Co. alone. On the other hand Tōhō Electric Power Co. was its own master.

This contrast was due to the difference in point of administrative ability of managers of the two electric power companies. Owing to loose-spending management by Shōhachi Wakao, the president from 1926 to 1930, Tokyo Electric Light Co. was in financial difficulties. 
Therefore Tokyo Electric Light Co. could not pay back debts from the Mitsui Bank sufficiently during the latter half of 1920's. Shigeaki Ikeda, the head of the managing directors of the Mitsui Bank interfered in human affairs concerning directors of Tokyo Electric Light Co.. Firstly he dispatched Seinosuke Gō and Ichizō Kobayashi in 1927. Secondly he changed the president from Wakao to Gō in 1930. Under capable management by Gō and Kobayashi Tokyo Electric Light Co. recovered itself in the 1930's. The Mitsui Bank had never intervened in Tokyo Electric Light Co. directly after 1930.

The intervening in Tokyo Electric Light Co. by the Mitsui Bank was a temporary phenomenon in order to preserve credits. The Mitsui Bank had never intervened in Tōhō Electric Power Co. which could pay back debts sufficiently under excellent management by the president Yasuzaemon Matsunaga. Therefore the commonly accepted theory is not adequate, which asserts that electric power capital was put under the control of Zaibatsu. 